BEATRIZ DIB NAMI

BENEFÍCIOS CREDITÍCIOS E FINANCEIROS COMO INSTRUMENTOS JURÍDICOS DE ATUAÇÃO DO ESTADO

\author{
Dissertação de Mestrado
}

Orientador: José Maria Arruda de Andrade

UNIVERSIDADE DE SÃO PAULO

FACULDADE DE DIREITO

São Paulo - SP

2020 



\section{BENEFÍCIOS CREDITÍCIOS E FINANCEIROS COMO INSTRUMENTOS JURÍDICOS DE ATUAÇÃO DO ESTADO}

Dissertação de Mestrado apresentada a Banca Examinadora do Programa de Pós-graduação em Direito, da Faculdade de Direito da Universidade de São Paulo, na área de concentração Direito Econômico, Financeiro e Tributário, sob orientação do Professor Associado José Maria Arruda de Andrade.

São Paulo - SP 
Autorizo a reprodução e divulgação total ou parcial deste trabalho, por qualquer meio convencional ou eletrônico, para fins de estudo e pesquisa, desde que citada a fonte.

Catalogação na publicação

Serviço de Biblioteca e Documentação

Faculdade de Direito da Universidade de São Paulo

Nami, Beatriz Dib

BENEFÍCIOS CREDITÍCIOS E FINANCEIROS COMO INSTRUMENTOS JURÍDICOS DE ATUAÇÃO DO ESTADO; Beatriz Dib Nami ; orientador José Maria Arruda de Andrade - São Paulo, 2020. 169.

Dissertação (Mestrado - Programa de Pós-Graduação em Direito Econômico, Financeiro e Tributário) - Faculdade de Direito, Universidade de São Paulo, 2020.

1. Benefícios creditícios e financeiros. 2. Atuação do Estado. 3. Controle interno e externo. 4. Tribunal de Contas da União - TCU. I. Andrade, José Maria Arruda de, orient. II. Título. 
NAMI, Beatriz Dib. Benefícios creditícios e financeiros como instrumentos jurídicos de atuação do Estado. 2019. 169 p. Dissertação (Mestrado em Direito) - Faculdade de Direito, Universidade de São Paulo, São Paulo, 2020.

Aprovada em:

Banca Examinadora

Prof. Dr.

Instituição:

Julgamento:

Prof. Dr.

Instituição:

Julgamento:

Prof. Dr.

Instituição:

Julgamento: 

Ao meu avô Dirmas, que vibra, em algum lugar melhor, com esta conquista. 



\section{AGRADECIMENTOS}

Esta intensa caminhada só foi possível graças às pessoas que me acompanharam e apoiaram em seus momentos bons e ruins. 2019 não foi um ano fácil: dentre grandes conquistas e inúmeros obstáculos, alguns agradecimentos são necessários.

Ao meu orientador, José Maria Arruda de Andrade, que, desde 2009, me apoia com generosidade e conhecimento ímpares. Talvez, naquela nossa primeira conversa, ainda na graduação, não imaginasse que chegaríamos até aqui em uma relação tão produtiva. Que sorte a minha.

Aos meus pais, Nami e Eliana, por todo o apoio e incentivo à minha educação. Sem vocês ao meu lado de forma incondicional nada seria possível. Vocês são meu grande exemplo de integridade e ética na vida pessoal e profissional. Obrigada por tanto.

À minha irmã, Isabela, por me tirar constantemente da zona de conforto e me provocar reflexões sem as quais eu não chegaria até aqui.

Ao meu companheiro de vida, Renan. Você está presente em todos os momentos, bons e ruins, sabe das minhas angústias e as resolve com um simples olhar. À sua serenidade que me completa e muda a minha vida diariamente. Nosso amor me acompanhou por todo esse caminho e, com certeza, é apenas o começo.

Aos amigos que me acompanham nessa jornada desde que me mudei para a Capital, Beatriz Vico, Bruna Amaral Vieira e Fernanda Zavatieri. Vocês são a família que escolhi a 438 quilômetros de casa. Obrigada pela apoio nesta e em tantas outras caminhadas.

Aos amigos que as Arcadas me trouxeram, Leonardo Branco, Daniel Gelcer, Paula Zugaib e, especialmente, Andrei Aguiar, amigo muito mais que querido e parte da minha família.

Às Arcadas, por me trazerem a reflexão e humanidade que me faltavam.

31 de dezembro de 2019 

NAMI, Beatriz Dib. Benefícios creditícios e financeiros como instrumentos jurídicos de atuação do Estado. 2019. 164 p. Dissertação (Mestrado em Direito) - Faculdade de Direito, Universidade de São Paulo, São Paulo, 2020.

\section{RESUMO}

A presente dissertação de mestrado tem o objetivo de colocar luz à discussão que circunda os benefícios creditícios e financeiros, até o momento pouco explorados frente à relevância que apresentam em termos orçamentários. Para isso localizaremos a discussão dentro do Direito Econômico. Entender os referidos benefícios como essenciais à compreensão da política econômica adotada pelo Estado e como instrumento relevante para o alcance dos objetivos traçados pela Constituição Econômica de 1988 é essencial ao desenvolvimento do trabalho. A atuação do Estado por meio da eleição de instrumentos como os benefícios creditícios e financeiros será olhada como integrante de uma política econômica e de diretrizes estabelecidas pela própria Constituição. A compreensão de necessidade de planejamento para a coerência da política adotada também será objeto de análise. Após, os benefícios serão localizados dentro do orçamento. O estudo das peças orçamentárias mais essenciais ao funcionamento do sistema será relevante para a localização do benefícios creditícios e financeiros. Contudo, focaremos na questão da despesa pública, tendo em vista a natureza dos referidos benefícios. Como mencionamos, a intenção é iluminar a discussão ainda nebulosa sobre o assunto. Feita a localização dos referidos instrumentos econômicos dentro do sistema econômico e orçamentário, passaremos à análise do controle e dos benefícios em si, bem como selecionaremos alguns para que se entenda a importância da análise feita em conjunto pela Administração Pública - controle interno - e pelo Tribunal de Contas da União controle externo. Assim, proporemos o estudo de alguns benefícios escolhidos estrategicamente, tendo em vista os acórdãos do TCU que tratam do tema e o comportamento da Administração Pública a partir dessas análises.

Palavras-chave: Benefícios creditícios e financeiros. Atuação do Estado. Despesa pública. Economicidade. Controle interno e externo. Tribunal de Contas da União. 

NAMI, Beatriz Dib. Credit and financial benefits as legal instruments of State action. 2019. 164 p. Dissertation (Master's in Law) - Faculdade de Direito, Universidade de São Paulo, São Paulo, 2020.

\begin{abstract}
This dissertation aims to shed light on the discussion surrounding the credit and financial benefits, so far little explored due to their relevance in budget terms. For this we will identify the discussion within the Economic Law. Understanding these benefits as essential to the comprehension of the economic policy adopted by the state and as a relevant instrument to achieve the objectives set by the 1988 economic Constitution is essential to the development of this dissertation. The State's performance through the option of instruments such as credit and financial benefits will be seen as part of an economic policy and guidelines established by the Constitution itself. Realize the requirement for planning for policy coherence will also be analyzed. Afterwards, benefits will be located within budget. The study of the most essential budget pieces to the system operation will be relevant to the location of the credit and financial benefits. However, we will focus on the public expenditure, given the nature of these benefits. As we mentioned, the intention is to illuminate the still nebulous discussion on the subject. Once these economic instruments are located within the economic and budgetary system, we will analyze the control and the benefits, as well as select some to understand the importance of the analysis made jointly by the Public Administration - internal control - and the Federal Audit Court (TCU) - external control. Thus, we will propose the study of some strategically chosen benefits, considering the TCU judgments that deal with the theme and the behavior of the Public Administration from these analyzes.
\end{abstract}

Keywords: Credit and financial benefits. State action. Public expenditure. Economy. Internal and external control. Federal Audit Court. 



\section{SUMÁRIO}

INTRODUÇÃO

1 O DIREITO ECONÔMICO, A CONSTITUIÇÃo FEDERAL DE 1988 E A ATUAÇÃO DO ESTADO

1.1 O Direito Econômico e a presença do Estado na Economia

1.1.1 O Direito Econômico e sua importância na análise da política econômica adotada pelo Estado

1.1.2 Intervenção e ideologia: matrizes ideológicas da atuação do Estado na economia ......29

1.2 Intervenção do Estado na economia e as Constituições brasileiras .35

1.2.1 Evolução e "desenho da intervenção" nas Constituições brasileiras 38

1.2.2 A Constituição Federal de 1988 e a posição atual sobre a atuação do Estado na economia

1.2.3 Promoção do desenvolvimento enquanto objetivo da atuação do Estado. 48

1.3 Constituição Econômica versus Constituição Financeira: o importante diálogo entre o Direito Econômico e o Direito Financeiro

\section{ASPECTOS ORÇAMENTÁRIOS DOS BENEFÍCIOS CREDITÍCIOS E}

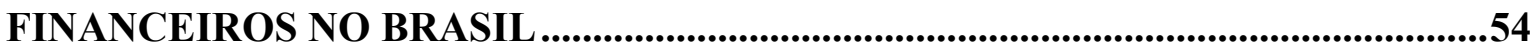

2.1 O Orçamento e o planejamento .54

2.1.1 Plano Plurianual (PPA), Lei de Diretrizes Orçamentárias (LDO) e Lei Orçamentária Anual (LOA)

2.1.2 Planejamento e o viés finalístico do Plano Plurianual ................................................68

2.2 Despesa pública: conceito, fontes e regime jurídico da despesa pública no Brasil ...........72

2.3 A dívida pública no Brasil: pontos principais para a compreensão do tema .....................77

2.4 Benefícios creditícios e financeiros: localizando estes incentivos no orçamento (e fora dele)

2.4.1 Incentivos estatais: benefícios tributários, creditícios e financeiros.

3 ECONOMICIDADE DOS BENEFÍCIOS CREDITÍCIOS E FINANCEIROS NA CONJUNTURA BRASILEIRA: O IMPORTANTE DIÁLOGO ENTRE A ADMINISTRAÇÃO PÚBLICA FEDERAL E O TRIBUNAL DE CONTAS DA UNIÃO

3.1 Economicidade: a abrangência e escopo pretendidos pelo trabalho 


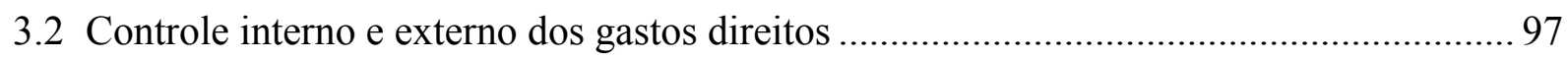

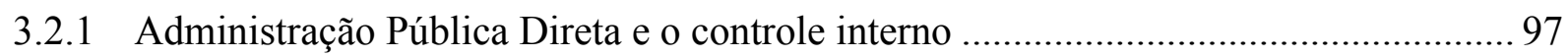

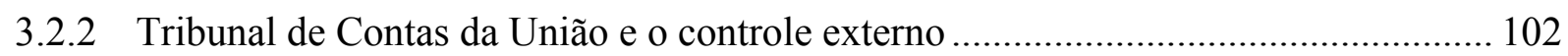

3.2.3 O diálogo entre a Administração Pública Federal e o TCU: economicidade

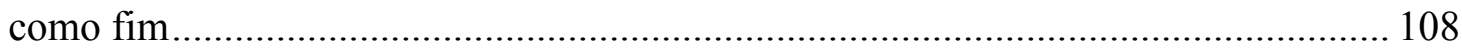

3.3 Benefícios creditícios e financeiros: análise do controle existente sobre alguns benefícios

3.3.1 Setor social

3.3.1.1 Subvenção a Consumidores de Energia Elétrica da Subclasse Residencial Baixa Renda

3.3.1.2 Fundo de Financiamento Estudantil (FIES) .......................................................... 118

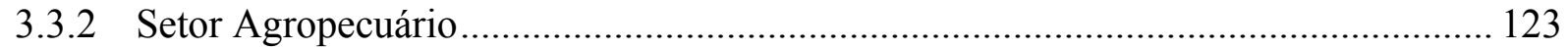

3.3.2.1 Subvenção ao Prêmio de Seguro Rural (PSR) ........................................................... 123

3.3.2.2 Programa Nacional de Agricultura Familiar (PRONAF) ....................................... 127

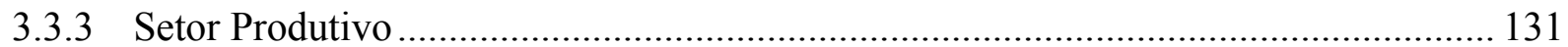

3.3.3.1 Programa de Sustentação de Investimento (PSI) .................................................. 131

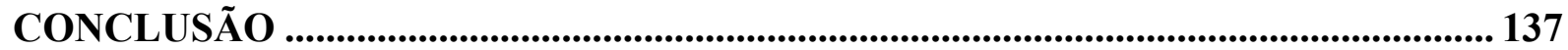

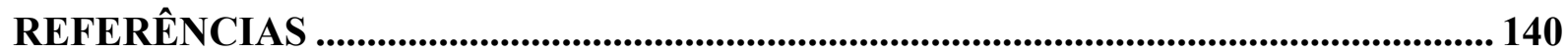

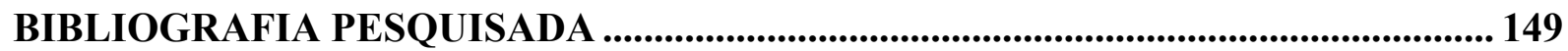

ANEXO - Demonstrativo de Benefícios Creditícios e Financeiros 2018 ........................... 156 


\section{INTRODUÇÃO}

Com a intenção de conformar a realidade brasileira ao modelo socioeconômico postulado na Constituição Federal, o Estado atua no Domínio Econômico com o fim de concretizar suas metas. São alguns os instrumentos possíveis para a concretização desse objetivo, mas neste trabalho estudaremos especificamente o caso dos benefícios creditícios e financeiros.

Voltaremos nossa atenção à modalidade de atuação do Estado sobre o Domínio Econômico, no que diz respeito aos benefícios creditícios e financeiros. Instrumento de política econômica usado de forma relevante pelo Estado para dar concretude a uma determinação constitucional, os benefícios em questão são pouco explorados pela doutrina como um todo. São ilustres desconhecidos que possuem um interessante campo de estudo quando associados não apenas ao Direito Econômico, mas também Financeiro. ${ }^{1}$

Embora previstos expressamente, os benefícios creditícios e financeiros na Constituição Federal, artigo 165 , parágrafo $6^{\circ}$, pouco se tratou do tema do ponto de vista jurídico. Nossa intenção é acender luz sobre o assunto, relacionando-o diretamente, bem como demonstrando sua importância quando analisados em um contexto de Direito Econômico, Financeiro e Administrativo.

Ao lado das renúncias tributárias (gastos tributários indiretos, materializados por meio de isenções e regimes tributários específicos), sobre o que discorreremos brevemente, os benefícios financeiros e creditícios são gastos efetivamente feitos, ainda que indiretamente, pelo governo com vistas a conceder créditos subsidiados, equalizar juros de créditos, preços subsidiados e assunção de dívidas de fundos.

Ao conceder créditos, subsidiar o fornecimento de produtos ou estabelecer fundos com recursos subsidiados, o Estado, praticando valores inferiores aos de mercado, assume um gasto efetivo ou postergado, sendo o beneficiário daquele subsídio o tomador do crédito, o comprador do produto ou o sujeito que se vale dos referidos fundos.

Fato é que as renúncias federais chegaram, em 2014, no montante de R\$302,3 bilhões, dos quais R $\$ 58,6$ bilhões corresponderam a esses benefícios creditícios e financeiros, de acordo com o Relatório e Parecer sobre as Contas do Governo da República de 2014. Em

ANDRADE, José Maria Arruda de. Benefícios Creditícios e Financeiros: esses ilustres desconhecidos. Consultor Jurídico, São Paulo, 14 ago. 2016. Disponível em: <https://www.conjur.com.br/2016-ago14/estado-economia-beneficios-financeiros-crediticios-ilustres-desconhecidos>. Acesso em: 17 nov. 2019. 
2015, o valor desses benefícios chegou a R\$ 107,7 bilhões. ${ }^{2}$ Em 2018, a concessão de benefícios tributários, financeiros e creditícios representou uma perda de receita orçamentária para o governo federal no montante projetado de $\mathrm{R} \$ 314,2$ bilhões, sendo $\mathrm{R} \$ 292,8$ bilhões de benefícios tributários e R $\$ 21,4$ bilhões de financeiros e creditícios. Valor expressivo e de análise indispensável.

Apesar de sucessivas quedas após 2015, chegando a 4,6\% do Produto Interno Bruto (PIB) em 2018, há certa estabilidade dos benefícios tributários e redução acentuada dos financeiros e creditícios.

A trajetória decrescente dos benefícios creditícios e financeiros, dentre outros motivos possíveis, foi fruto essencialmente da revisão de alguns programas, como Fundo de Financiamento Estudantil (Fies), Programa Nacional de Fortalecimento da Agricultura Familiar (Pronaf) e Programa de Sustentação do Investimento (PSI), bem como da redução nominal de valores associados ao Fundo de Amparo ao Trabalhador (FAT) e ao Banco Nacional de Desenvolvimento (BNDES).

Assim, no exercício de 2018, os benefícios financeiros e creditícios da União alcançaram R\$ 21,4 bilhões, correspondendo a uma redução de quase $75 \%$ em relação a $2017 .^{3}$

Portanto, o volume de recursos financeiros, o impacto fiscal de sua utilização sobre a dívida pública e o uso desses subsídios para programas de natureza econômico-social, justificam e até impõem o conhecimento e a análise de suas características por parte dos estudiosos de Direito Econômico e Financeiro.

Partindo da Constituição Federal, o artigo 165 , parágrafo $6^{\circ}$, determina que o projeto de lei orçamentária deverá ser acompanhado de demonstrativo regionalizado do efeito dos benefícios de natureza financeira, tributária e crediticia sobre as receitas e despesas. Para além da Constituição, o artigo $5^{\circ}$, II, da LC $n^{\circ}$ 101/2000 também estabelece que o projeto de Lei Orçamentária Anual deverá vir acompanhado daquele demonstrativo regionalizado dos efeitos desses benefícios acima mencionados.

A alusão a esses benefícios, sem maiores definições, delimitações ou outros pormenores já abre a necessidade de esclarecimento para cumprimento necessário do estabelecido em texto constitucional e infraconstitucional acerca da matéria. O presente trabalho, ao realizar esforço de localização dos benefícios no modelo de Estado pretendido

2 BRASIL. TCU. Relatório e Parecer Prévio sobre as Contas do Governo da República - Exercício de 2014. Relator: Augusto Nardes. Brasília: TCU, 2014. Disponível em: <https://portal.tcu.gov.br/tcu/paginas/ contas_governo/contas_2014/index.html>. Acesso em: 17 nov. 2019.

3 Ibid. 
pelo constituinte de 88, passa a estudar os gastos diretos dentro da lógica financeira, orçamentária e extraorçamentária, para compreensão adequada do tema.

A partir dessas determinações e da própria atividade de fiscalização externa do Tribunal de Contas da União (TCU), coube ao Ministério da Fazenda construir uma definição para a realidade brasileira do que seriam esses benefícios, de quais se tratariam (programas e fundos) e de como avaliar cada um.

Com a localização do assunto dentro do espectro do Direito Econômico e do Direito Financeiro, podemos definir os subsídios objeto de estudo com adequação necessária, já que agora são entendidos dentro do todo. Assim, os benefícios creditícios, considerados implícitos, podem ser compreendidos como subsídios que decorrem de programas oficiais de crédito concedidos a taxas de juros inferiores ao custo de captação do governo e que são operacionalizados por meio de fundos ou programas. Pelo fato de esses gastos não aparecem no orçamento vinculados diretamente aos benefícios que foram concedidos, mas sim a outras despesas como serviços da dívida pública, o estudo para além da despesa pública será necessário.

Já os benefícios financeiros são transferências correntes ou desembolsos efetivos feitos pelo governo federal para equalizar juros ou preços ou para a assunção das dívidas decorrentes de saldos de obrigações de responsabilidade do Tesouro Nacional.

Não é nosso objetivo esgotar a análise dos benefícios creditícios e financeiros existentes atualmente. Levando em conta nossa base de análise, qual seja a governança desses benefícios, escolhemos 5 (cinco) subsídios relevantes em termos quantitativos e que, em algum momento, tiveram algum elemento relevante analisado pelo Tribunal de Contas da União e pela Administração Pública interna. Nesse sentido, justifica-se nossa opção pelo estudo da Subvenção a Consumidores de Energia Elétrica da Subclasse Residencial Baixa Renda, Fundo de Financiamento Estudantil (FIES), Subvenção ao Prêmio de Seguro Rural (PSR), Programa Nacional de Agricultura Familiar (PRONAF) e Programa de Sustentação de Investimento (PSI).

No que toca a Administração Pública interna, verificaremos a movimentação em termos de sua organização no sentido de distribuição de competências para gestão desses subsídios. Atualmente, a Secretaria de Acompanhamento Fiscal, Energia e Loteria (Sefel) do Ministério da Economia é a sucessora da Secretaria de Política Econômica (SPE) na competência para análise da gestão desses subsídios.

A Portaria $n^{\circ} 379 / 2006$ (artigo $4^{\circ}$ ) do Ministério da Fazenda, atual Ministério da Economia, atribui à Secretaria de Política Econômica a competência para elaborar o 
demonstrativo que acompanha o projeto da LOA, elaborar a apuração regionalizada de cada programa ou fundo para a análise do TCU e avaliar o seu impacto nos resultados fiscais e a efetividade daquelas políticas. Como mencionamos, essa competência hoje é da Secap.

Quando o governo federal constrói uma política econômico-social para subsidiar créditos com juros inferiores aos de captação, com preços inferiores aos de mercado ou assume dívidas de fundos, esses gastos devem ser apurados, regionalizados e estudados pelo governo, seja para informar o PLOA, seja para prestar contas ao TCU.

No que toca o controle externo, veremos que o Acórdão n ${ }^{\circ}$ 1.718/2005-TCU Plenário foi um importante marco na governança desses benefícios. Desde então, há uma preocupação crescente com os benefícios e sua aplicação. Buscaremos compreender a evolução desse julgado tanto na jurisprudência do próprio Tribunal quanto no comportamento da Administração Pública interna.

A doutrina relacionada ao controle, tanto interno quanto externo, nos demonstrará de que maneira, e por quais razões, a condução das atividades públicas avançou para, hoje, sujeitar-se a responder não apenas pela legalidade de seus atos, mas também pela adequação e eficiência de sua conduta. Mecanismos de controle interno e externo da administração pública serão apresentados, a fim de introduzir o papel do Tribunal de Contas da União (TCU) neste trabalho.

A escolha do tema é justificada, em parte, por sua relevância perante a atual conjuntura nacional. O Brasil enfrentou um cenário de recessão econômica, tendo apresentado déficits fiscais desde o ano de 2014 - sendo que as projeções apontam que a situação negativa deve perdurar até o ano de 2020. Apesar de o déficit fiscal apresentado no ano de 2018 ter sido inferior àquele reportado no ano de 2017, o seu montante ainda é expressivo, representando $1,6 \%$ do Produto Interno Bruto (PIB). ${ }^{4}$

Após contínuos exercícios fiscais em que a expansão do gasto foi financiada pela dívida pública, refletindo, por consequência, na dívida líquida em comparação ao PIB, a

4 Na nossa visão é importante já relativizarmos que a crítica indiscriminada ao elevado endividamento público é, por si só, problemática. As despesas estatais atendem a pressupostos constitucionais, dentre os quais a prestação de serviços públicos, o atendimento de direitos sociais e redução de desigualdades, fins constitucionalmente previstos que devem ser buscados ativamente pelo Estado às suas expensas. Sobre a necessidade de se ponderar acerca do custo da dívida, citamos: "A partir da década de 1980, a retórica do controle do déficit público, vinculada ao discurso neoliberal de repúdio ao Estado, é acompanhada pelo aumento dos gastos públicos, graças às despesas com a política monetária, especialmente as altas taxas de juros. O déficit público defendido por autores como John Maynard Keynes e Michal Kalecki era o déficit público do pleno emprego. Hoje é o déficit público que garante a remuneração para o capital" (BERCOVICI, Gilberto; MASSONETTO, Luís Fernando. A constituição dirigente invertida: a blindagem da constituição financeira e a agonia da constituição econômica. Separata do Boletim de Ciências Econômicas, Coimbra, v. 49, 2006, p. 68). 
política fiscal do Governo Federal estruturou-se no ano de 2018 para tentar impedir o crescimento do endividamento da União. ${ }^{5}$

A Emenda Constitucional $n^{\circ} 95 / 2016$, que trouxe o Novo Regime Fiscal também conhecido como Teto dos Gastos, foi estabelecida com a finalidade de impedir o crescimento real das despesas públicas primárias, limitando-o à variação do Índice de Preços ao Consumidor Amplo (IPCA) ${ }^{6}$. Fato é que o quadro atual é de desequilíbrio fiscal, evitando-se qualquer juízo sobre a adequação das referidas medidas econômicas ou sobre a condução dos eventos políticos que se sucederam na última década. Há queda da arrecadação de receitas mesmo com a rigidez orçamentária imposta, sendo a escassez de recursos para a execução de política econômica uma decorrência lógica do quadro que se impõe.

A barreira à instituição de novos incentivos ou incremento em relação aos já existentes como fator necessário de promoção de objetivos econômico-sociais, em razão do esgotamento dos recursos públicos, denota a necessidade de avaliação dos resultados atingidos pelas políticas econômicas em vigor, bem como sua adequação aos objetivos pensados quando da sua criação.

O controle por nós entendido como imprescindível tem como finalidade munir o Estado das ferramentas necessárias à decisão sobre a permanência, incremento ou revogação dos benefícios. O questionamento sobre a eficiência desses incentivos para alcançar os objetivos para os quais foram instituídos é essencial para a justificativa de necessidade e manutenção deles em um cenário como o atual brasileiro.

Por todo o panorama aqui apresentado, resta clara a importância do tema escolhido.

5 "O déficit primário de 2019 do SPC, segundo a abordagem das necessidades de financiamento do setor público (NFSPs) - ou cálculo 'abaixo da linha' - divulgada pelo $\mathrm{BCB}$, foi de 1,6\% do PIB, ligeiramente inferior ao de 2017 (1,7\% do PIB) e bem abaixo do pico recente, de 2,5\% do PIB, em 2016, e da própria meta fixada para o ano passado, de 2,3\% do PIB (gráfico 1 e tabela 1). Apesar dessa evolução, trata-se do quinto ano consecutivo de déficit primário. [...] A política fiscal em 2018 ilustra os avanços e os limites no sentido de manter a trajetória gradual de redução dos desequilíbrios. O fato de o déficit primário ter ficado bem abaixo do projetado um ano antes, mesmo com um desempenho do PIB inferior ao previsto, mostra que é possível reduzi-lo - por exemplo, por meio de medidas racionalizadoras, como as que vêm permitindo um menor crescimento das despesas com benefícios previdenciários devido a ações de combate às fraudes, ou de política econômica, como a redução de subsídios e subvenções. No entanto, o déficit primário permanece elevado do ponto de vista da dinâmica da dívida pública, e o escopo para reduções adicionais - em especial, os cortes de investimentos - vai se estreitando, na ausência de medidas estruturais que alterem a dinâmica de crescimento dos gastos. É o caso do peso das despesas obrigatórias no conjunto dos gastos públicos do governo federal, que corresponderam a 90,5\% dos gastos primários totais de 2018" (IPEA. Instituto de Pesquisa Econômica Aplicada. Carta de Conjuntura, Brasília, n. 42, p. 1-12, $1^{\circ}$ trimestre 2019. Disponível em: <http://www.ipea.gov.br/portal/images/stories/PDFs/conjuntura/190219_cc42_politica_fiscal.pdf $>$. Acesso em: 17 nov. 2019).

6 A EC 95, que vigorará por vinte exercícios financeiros, estabelece que o crescimento anual das despesas primárias deve estar limitado à variação do IPCA apurado no período de doze meses, encerrado em junho do exercício anterior a que se refere a lei orçamentária. O descumprimento do limite estabelecido será punível com medidas restritivas à criação de novas despesas até que o Poder Executivo ou o órgão em questão retorne aos limites previstos. 
A intenção deste trabalho é suprir, ainda que parcialmente, a escassez de estudos acadêmicos a respeito dos mecanismos de controle de eficiência dos benefícios creditícios e financeiros, bem como demonstrar a importância de estudos nesse sentido. Uma vez instituído o benefício, não há, em regra, avaliação periódica de resultados, de modo que são desconhecidos os benefícios sociais ou econômicos decorrentes de cada medida. Ter a vigência mantida a cada ano, sem que haja qualquer tipo de discussão no âmbito do Poder Executivo sobre a efetividade do benefício é um grande problema, não apenas aos benefícios vigentes, mas também aos que poderiam ser implementados em setores que necessitam da atuação direta do Estado.

Políticas econômicas que se valem de benefícios creditícios e financeiros como instrumentos de promoção do desenvolvimento são importantes no aperfeiçoamento das condições econômicas e sociais do país, de maneira que zelar pela eficiência na promoção dos objetivos que almeja é, ao mesmo tempo, respeitar as causas que ensejaram sua criação e possibilitar o seu perpetuamento de forma eficiente em setores que de fato necessitam.

Portanto, o controle de resultados é indispensável à boa saúde das finanças públicas e ao andamento de toda a sociedade, uma vez que composta por agentes econômicos que interagem entre si e com o Estado.

Para isso, fizemos um caminho doutrinário e normativo essencial ao estudo bibliográfico interdisciplinar publicado no Brasil. A pesquisa bibliográfica visa, como mencionamos, a contextualizar os benefícios creditícios e financeiros, e seus impactos na economia e na sociedade.

Muito embora a fundamentação teórica e doutrinária valha para tratar sobre a temática em geral, qualquer que seja o ente que os tenha instituído, neste trabalho tratamos somente dos federais. Cabe mencionar, todavia, que Estados e municípios ainda estão distantes do exercício transparente e efetivo do controle de suas renúncias. Os mecanismos de controle são quase inexistentes e as fiscalizações são pontuais e restritas. Pode-se afirmar que o desenvolvimento pelo qual o tema passou nas últimas décadas no âmbito federal não foi replicado nas demais esferas da Federação. ${ }^{7}$

Conforme mostrará a análise de alguns benefícios no terceiro Capítulo, a ideia é demonstrar em que medida as determinações do TCU têm despertado atenção aos mecanismos de controle dos subsídios, considerando não apenas seus aspectos financeiros,

ANDRADE, José Maria Arruda de. Ano Mostrou Seriamente a Necessidade de Discutir a Política Fiscal do País. Consultor Jurídico, São Paulo: Conjur, 24 dez. 2017. Disponível em: $<$ https://www.conjur.com.br/2017-dez-24/retrospectiva-2017-ano-mostrou- necessidade-discutir-politicafiscal>. Acesso em: 20 out. 2019. 
mas também averiguando a qualidade da gestão dessas políticas. Os trabalhos de físcalização realizados pelo Tribunal de Contas têm continuamente contribuído para a melhor compreensão do assunto dentro de outros órgãos da Administração. Isso porque as suas deliberações foram responsáveis por impulsionar o Poder Executivo a aperfeiçoar sua atividade de controle e aprimorar a coordenação entre os órgãos gestores.

Acreditamos que este trabalho poderá instigar a produção acadêmica, bem como orientar a atuação da Administração Pública, notadamente nos órgãos responsáveis pelo planejamento, implementação e controle dos benefícios. Nosso objetivo é colocar as bases doutrinárias que localizam esses benefícios no nosso ordenamento e ressaltar a importância de serem estabelecidos mecanismos de controle capazes de avaliá-los corretamente. 


\section{CONCLUSÃO}

Após a análise realizada por esta dissertação, é possível que se identifiquem alguns pontos relevantes para nossa conclusão.

A compreensão do Direito Econômico na análise da política econômica adotada pelo Estado, bem como dos objetivos traçados pela Constituição Econômica de 1988 servem de ponto de partida para a compreensão dos benefícios creditícios e financeiros. A importância de localizar os instrumentos de atuação do Estado na economia, objeto de análise deste estudo, dentro da doutrina específica do Direito Econômico é essencial ao nosso estudo. Com esta análise conseguimos entender, sem qualquer dúvida, a importância dos referidos instrumentos para realização do próprio texto constitucional. Os benefícios existem, são legítimos e impõem sua concretização por determinação constitucional.

Assim, restou claro que o Estado não deve se limitar a atuação mínima, mas dimensionar seus recursos e política econômica de maneira a satisfazer o mais amplamente possível as necessidades sociais. Os instrumento possíveis de política econômica tendem a garantir a manutenção da própria atividade econômica, bem como seu crescimento.

A identificação dos vieses orçamentários dos benefícios creditícios e financeiros e a identificação de elementos relevantes para a sua compreensão como as principais leis orçamentárias, a noção de planejamento, o conceito de despesa pública e dívida pública foram essenciais à compreensão de toda a técnica que circunda o tema. A definição do que é benefício creditício e financeiro em si passa pela compreensão das leis orçamentárias e dos elementos componentes e não componentes de um orçamento. A noção e localização dos benefícios dentro do que se entende por despesa orçamentária e extra orçamentária pretendeu trazer luz à discussão.

A compreensão de que planejamento não pode ser reduzido à noção de orçamento, pois perde sua principal característica, qual seja, a de fixar diretrizes para a atuação do Estado é chave na compreensão dos benefícios aqui expostos. O plano plurianual é uma previsão de gastos, essencial à gestão estatal, mas que pode ocorrer ou não, sem que qualquer órgão controle estritamente sua execução e ou garanta sua efetividade. A redução do referido plano ao orçamento pode levar à coordenação de forma mais controlada os gastos públicos, mas não se trata de verdadeiro planejamento, voltado à transformação das estruturas socioeconômicas do país. Por isso, não podemos perder de vista, bem como ressaltamos, que a necessidade de 
planejamento no Brasil, em momento algum, foi suprida pela tentativa de plano plurianual com viés finalístico relato neste trabalho.

Ter controle sobre os gastos públicos é relevante, conforme demonstrado, mas em nada se confunde com a necessidade de planejamento para desenvolvimento do país. A mera execução orçamentária e controle a partir do que dispõem as peças orçamentárias podem perder o foco da necessidade de direcionamento da política que se pretende atingir ao desenhar determinado benefício, seja em cumprimento ao planejamento geral ou para o setor, sempre em consonância com o disposto pela Constituição Federal.

Por fim, o desenvolvimento do conceito de economicidade, sob o aspecto de foco no estudo do controle interno e externo de alguns benefícios eleitos para análise, demonstraram o objetivo pretendido por esta dissertação. $\mathrm{O}$ vocábulo economicidade tem feição pluridisciplinar e optamos por destacar sua vinculação ao domínio da ciência econômica e das ciências que estudam gestão relacionada a desempenho qualitativo. Nesse sentido, trata-se da obtenção do melhor resultado estratégico possível de um determinada alocação de recursos financeiros, econômicos ou patrimoniais em cenário econômico específico.

Entender de que forma o TCU impulsiona a atuação da Administração Pública direta a realizar mudanças e adaptações necessárias ao benefício foi o grande objetivo desta dissertação. Não nos parece, por tudo que analisamos, que o controle de resultados de um determinado benefício seja algo simples ou até viável em sua plenitude, mas, a partir da provocação da Administração Pública para análise do instrumento, é possível que se retome um objetivo traçado e posteriormente desvirtuado ou entenda-se que outros resultados úteis são possíveis com a adoção da política. A resposta, a nosso ver, é a necessidade de planejamento de fato da política econômica que será adotada pelo Estado.

Interessante notar que do modo como desenvolvemos o raciocínio neste trabalho, o casamento de ideias se completa com a percepção do controle feito em alguns casos pelo TCU. O Tribunal de Contas, ao retomar (ou tentar retomar) o objetivo inicialmente traçado na criação do benefício, é capaz de avaliá-lo e sugerir medidas à Administração Direta para que retome o curso pretendido. Tudo passa pela necessidade de planejamento da política, como peça chave.

Ao iniciarmos as pesquisas para elaboração desta dissertação de mestrado, a pretensão de localizar os benefícios creditícios e financeiros em uma situação que os identificasse como medidas necessárias ao cumprimento dos objetivos constitucionais e ao mesmo tempo os localizasse em um contexto técnico orçamentário parecia uma ambição doutrinária longínqua. Some-se a isso a dificuldade de análise da economicidade pretendida pelo trabalho no cenário 
então vigente da Administração Pública e do Tribunal de Contas da União. Hoje, em que pesem as inúmeras fragilidades na estrutura de governança e gestão dessas medidas, a importância do controle foi reconhecida e encontra-se em crescente expansão.

O que observamos aqui é justamente que o TCU possui um papel relevante na medida em que visa provocar a Administração Pública sobre os pontos deficientes e questionáveis dos benefícios. Contudo, o papel principal é, a nosso ver, da Administração Pública direita criadora e gestora do benefício. Isto porque, incialmente, foi ela quem verificou a necessidade de implementação de tal política e, portanto, deve ser ela, hoje com auxílio externo do TCU, a promover as correções devidas.

Como ressaltamos, a análise do TCU deve fazer parte de um estágio intermediário até que se alcance a excelência nas avaliações (e na identificação da necessidade delas) por parte da própria Administração Pública interna. A educação e necessidade de avaliação provocadas pelo TCU, atualmente, são importantes, mas devem ser absorvidas pela Administração, a fim de que esta desenvolva sua própria forma de avaliar o benefício em consonância com o planejamento visto de uma forma global e para o setor, sendo o Tribunal de Contas chamado à análise apenas em situações excepcionais e dentro, exclusivamente, de sua competência constitucionalmente traçada. A Administração é, em verdade, a maior interessada e responsável pela condução adequada da política adotada e do benefício utilizado como instrumento de atuação no setor. 


\section{REFERÊNCIAS}

ADEODATO, Alberto. Manual de ciência das finanças. 4. ed. São Paulo: Saraiva, 1952.

ALMEIDA, Carlos Otávio Ferreira de. O planejamento financeiro responsável: boa governança e desenvolvimento do Estado contemporâneo. In: CONTI, José Mauricio; SCAFF, Fernando Facury (Coords.). Orçamentos públicos e direito financeiro. São Paulo: Revista dos Tribunais, 2011. p. 577-599.

ALMEIDA, Francisco Carlos Ribeiro de. Uma abordagem Estruturada da Renúncia de Receita Pública Federal. Revista do Tribunal de Contas da União, n. 84, p. 19-62, p. 2000.

ANDRADE, José Maria Arruda de. A Política Econômica e a Governança dos Gastos Tributários Indiretos. Consultor Jurídico, São Paulo: Conjur, 30 ago. 2015. Disponível em: $<$ http://www.conjur.com.br/2015-ago-30/estado-economia-politica-gastos-tributariosindiretos>. Acesso em: 20 out. 2019.

Ano Mostrou Seriamente a Necessidade de Discutir a Política Fiscal do País.

Consultor Jurídico, São Paulo: Conjur, 24 dez. 2017. Disponível em: $<$ https://www.conjur.com.br/2017-dez-24/retrospectiva-2017-ano-mostrou- necessidadediscutir-politica-fiscal $>$. Acesso em: 20 out. 2019.

Avaliação de eficiência e efetividade é necessária em nossa política econômica. Consultor Jurídico, São Paulo: Conjur, 21 fev. 2016. Disponível em: $<$ https://www.conjur.com.br/2016-fev-21/estado-economia-avaliacao-eficiencia-necessarianossa-politica-economica>. Acesso em: 01 out. 2019.

. Benefício financeiro da tarifa social de energia de consumidores de baixa renda. Consultor Jurídico, São Paulo: Conjur, 09 out. 2019.

- Benefícios Creditícios e Financeiros: esses ilustres desconhecidos. Consultor Jurídico, São Paulo, 14 ago. 2016. Disponível em: <https://www.conjur.com.br/2016-ago14/estado-economia-beneficios-financeiros-crediticios-ilustres-desconhecidos $>$. Acesso em: 17 nov. 2019.

ANEEL. Boletim Mensal sobre Subsídios da União - Conta de Desenvolvimento Energético Subsídios Públicos ou Cruzados? Edição 7. Brasília, abr. 2019.

ATALIBA, Geraldo. Empréstimos públicos e seu regime jurídico. São Paulo: Revista dos Tribunais, 1973.

BALEEIRO, Aliomar. Uma introdução à ciência das finanças. 16. ed. Rio de Janeiro: Forense, 2008.

BANDEIRA DE MELlO, Celso Antônio. Curso de Direito Administrativo. 17. ed. São Paulo: Malheiros, 2004.

BASTOS, Celso Ribeiro. Direito econômico brasileiro. São Paulo: Instituto Brasileiro de Direito Constitucional, 2000. 
BERCOVICI, Gilberto. A Constituição dirigente e a crise da teoria da Constituição. In: BERCOVICI, Gilberto; LIMA, Martonio Mont'Alverne B.; MORAES FILHO, José Filomeno; SOUZA NETO, Cláudio Pereira. Teoria da Constituição: estudos sobre o lugar da política no direito constitucional. Rio de Janeiro: Lumen Juris, 2003. p. 75-150.

. As origens do Direito Econômico: homenagem a Washington Peluso Albino de Souza. Revista da Faculdade de Direito da UFMG, Número especial em memória do Professor Washington Albino Peluso de Souza, p. 253-263, 2013.

Constituição e Estado de Exceção Permanente: Atualidade de Weimar. Rio de Janeiro: Azougue Editorial, 2004.

Constituição Econômica e Desenvolvimento: uma leitura a partir da Constituição de 1988. São Paulo: Malheiros, 2005.

Desigualdades regionais, estado e Constituição. São Paulo: Max Limonad, 2003.

2011.

Direito Econômico do Petróleo e dos Recursos Minerais. São Paulo: Quartier Latin,

. O ainda indispensável direito econômico. In: BENEVIDES, Maria Victoria de Mesquita; BERCOVICI, Gilberto; MELLO, Claudineu de. (Org.). Direitos humanos, democracia e república: homenagem a Fábio Konder Comparato. São Paulo: Quartier Latin, 2009. p. 503-519.

. Parecer sobre a inconstitucionalidade da Medida Provisória da Liberdade Econômica (Medida Provisória no 881, de 30 de abril de 2019). Revista Fórum de Direito Financeiro e Econômico - RFDFE, Belo Horizonte, ano 8, n. 15, p. 173-202, mar./ago. 2019.

. Soberania e Constituição: para uma crítica do constitucionalismo. São Paulo: Quartier Latin, 2008.

; MASSONETTO, Luís Fernando. A Constituição Dirigente Invertida: A Blindagem da Constituição Financeira e a Agonia da Constituição Econômica. Revista de Direito Mercantil Industrial, Econômico e Financeiro, v. 45, p. 79-89, 2007.

; _. A constituição dirigente invertida: a blindagem da constituição financeira e a agonia da constituição econômica. Separata do Boletim de Ciências Econômicas, Coimbra, v. 49, p. 57-77, 2006.

BIELSCHOWSKY, Ricardo. As contribuições de Celso Furtado ao estruturalismo e sua atualidade. In: SABOIA, João; CARVALHO, Fernando J. Cardim de (Orgs). Celso Furtado e o Século XXI. Rio de Janeiro: Manole, 2007. p. 431-445.

- Cinquenta anos de Pensamento da CEPAL - uma resenha. In: Cinquenta anos de Pensamento da CEPAL. Rio de Janeiro: Record, 2000. p. 13-68. (Org.).

. Pensamento Econômico brasileiro: o ciclo ideológico do desenvolvimentismo. 4.

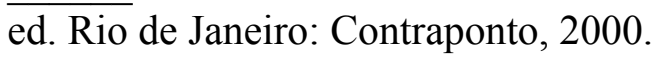

BRASIL. Ministério da Economia. Demonstrativo de Benefícios Creditícios e Financeiros 2018. Brasília, 2018. Disponível em: <http://www.fazenda.gov.br/centrais-de- 
conteudos/publicacoes/demonstrativos-financeiros-e-crediticios/beneficios-financeiros-ecrediticios/demonstrativo-de-beneficios-financeiros-e-crediticios-2018>. Acesso em: 16 nov. 2019.

. Ministério da Economia. Receita Federal. Demonstrativos dos Gastos Tributários DGT. Brasília, 25 nov. 2014, modificado em 4 set. 2018. Disponível em: http://receita.economia.gov.br/dados/receitadata/renuncia-fiscal/previsoes-ploa/arquivos-eimagens/demonstrativos-dos-gastos-tributarios-dgt>. Acesso em: 26 jun. 2019.

. Ministério da Economia. SECAP. Boletim Mensal de Subsídios da União. Uma Análise dos Subsídios (Gastos) Tributários da União: evolução e comparação internacional. Brasília, jun. 2019. Disponível em: <http://www.fazenda.gov.br/centrais-deconteudos/publicacoes/orcamento-de-subsidios-da-uniao/arquivos/boletim-mensal-sobre-ossubsidios-da-uniao-analise-dos-subsidios-gastos-tributarios-da-uniao-evolucao-e-comparacaointernacional>. Acesso em: 02 jul. 2019.

Ministério da Economia. Secretaria de Acompanhamento Econômico. Orçamento de Subsídios da União. Relatório do Governo Federal sobre a evolução dos gastos tributários e benefícios financeiros e creditícios no período de 2003 a 2016. Brasília, 2017. Disponível em: $<$ http://www.fazenda.gov.br/centrais-de-conteudos/publicacoes/orcamento-de-subsidiosda-uniao/arquivos/orcamento-de-subsidios-da-uniao-2016.pdf>. Acesso em: 13 out. 2019.

Ministério da Economia. Secretaria de Acompanhamento Fiscal, Energia e $\overline{\text { Loteria }}$ (Sefel). Brasília, 2019. Disponível em: <http://www.fazenda.gov.br/orgaos/sefel $>$. Acesso em: 10 jun. 2019.

Ministério da Economia. Secretaria de Política Econômica do Ministério da Fazenda. Demonstrativo de Benefícios Financeiros e Creditícios. Brasília, 20 abr. 2018. Disponível em: $<$ http://www.fazenda.gov.br/centrais-de-conteudos/publicacoes/demonstrativos-financeiros-ecrediticios>. Acesso em: 25 abr. 2018.

Ministério da Economia. Secretaria de Política Econômica. Brasília, 2019. Disponível em: $\quad<$ http://www.spe.fazenda.gov.br/assuntos/politica-fiscal-etributaria/beneficios-financeiros-e-crediticios/demonstrativo2014.pdf $>$. Acesso em: 24 abr. 2019.

. Ministério da Economia. Tesouro Nacional. Dívida Pública - Conceitos Básicos. Brasília, 2019. Disponível em: <http://www.tesouro.fazenda.gov.br/conceitos-basicos-faq $>$. Acesso em: 12 out. 2019.

. Ministério da Fazenda. SEAE. As alterações propostas no Fies. MP 785/2017. Brasília, 2017.

Ministério da Fazenda. Secretaria de Acompanhamento Fiscal, Energia e Loteria. Processo SEI n ${ }^{0}$ 18101.100462/2018-91. Brasília, 19 jul. 2018.

- TCU. Auditoria Operacional do Fundo de Financiamento Estudantil (FIES). Brasília: TCU, 01 jan. 2016. Disponível em: <https://portal.tcu.gov.br/bibliotecadigital/auditoria-operacional-no-fundo-de-financiamento-estudantil-fies.htm>. Acesso em: 25 dez. 2019.

. TCU. Disponível em: <https://portal.tcu.gov.br>. Acesso em: 15 nov. 2017. 
. TCU. Manual de Auditoria Financeira. Brasília, $1^{\circ}$ jan. 2016. Disponível em: $\overline{<\mathrm{https}}$ //portal.tcu.gov.br/biblioteca-digital/manual-de-auditoria-financeira.htm $>$. Acesso em: 26 jun. 2019.

. TCU. Manual de Auditoria Operacional. Brasília: TCU, Secretaria de Fiscalização e Avaliação de Programas de Governo (Seprog), 2010. Disponível em: $<$ https://portal.tcu.gov.br/controle-externo/normas-e-orientacoes/normas-defiscalizacao/auditoria-operacional.htm>. Acesso em: 14 out. 2019.

2017.

TCU. Relatório de Fiscalização n 151/2017. Relator: André de Carvalho. Brasília,

TCU. Relatório do Acórdão no 1.718/2005. Relator: Augusto Sherman Cavalcanti. Sessão: 26 out. 2005. Órgão Julgador: Plenário. Brasília, 2005. Disponível em: $<$ https://pesquisa.apps.tcu.gov.br/\#/documento/acordao-completo/*/KEY\%253AACORDAOCOMPLETO-22323/DTRELEVANCIA\%2520desc/0/sinonimos\%253Dfalse>. Acesso em: 28 jun. 2018.

TCU. Relatório e Parecer Prévio sobre as Contas do Governo da República Exercício de 2014. Relator: Augusto Nardes. Brasília: TCU, 2014. Disponível em: $<$ https://portal.tcu.gov.br/tcu/paginas/contas_governo/contas_2014/index.html $>$. Acesso em: 17 nov. 2019.

. TCU. Relatório e Parecer Prévio sobre as Contas do Presidente da República. Relatora: Ministra Ana Arraes. Brasília, 2018. Disponível em: $<$ https://portal.tcu.gov.br/contas-do-governo/index.html>. Acesso em: 17 nov. 2019.

. TCU. Resolução $\mathbf{n}^{0}$ 240, de 23 de dezembro de 2010. Define a estrutura, as competências e a distribuição das funções de confiança das unidades da Secretaria do Tribunal de Contas da União. Brasília: 3 jan. 2011.

. TCU. Tarifa Social e Desafios da Universalização dos Serviços de Energia Elétrica no Brasil. Brasília: TCU, 16 jun. 2008. Disponível em: $<$ https://portal.tcu.gov.br/biblioteca-digital/tarifa-social-e-desafios-da-universalizacao-dosservicos-de-energia-eletrica-no-brasil.htm>. Acesso em: 08 jul. 2018.

CABRAL, Nazaré da Costa. Programação e decisão orçamental: da racionalidade das decisões orçamentais à racionalidade econômica. Coimbra: Almedina, 2008 (Coleção Teses de Doutoramento).

CANOTILHO, José Joaquim Gomes. Constituição dirigente e vinculação do legislador: contributo para a compreensão das normas constitucionais programáticas. Reimpressão. Coimbra: Coimbra, 1994.

CARDONA, Alejandro Ramirez. Sistema de hacienda pública. Bogotá: Temis, 1970.

CARVAlHO FILHO, José dos Santos. Manual de Direito Administrativo, $25^{\circ}$ Ed. Rev., ampl. e atual. até a Lei no 12. 587, de 3-1-2012 - São Paulo: Atlas, 2012.

CARVAlHOSA, Modesto Souza Barros. Direito Econômico. São Paulo: Revista dos Tribunais, 1973. 
Considerações sobre Direito Econômico. 1971. Tese (Doutorado em Direito) Universidade de São Paulo, São Paulo, 1971.

CHANG, Hoo-Joon. Chutando a Escada: A Estratégia do Desenvolvimento em Perspectiva Histórica. São Paulo: Unesp, 2004.

CHENOT, Bernard. Organisation Économique de L’ État. Paris: Dalloz, 1951.

CLARK, Giovani; CORRÊA, Leonardo; NASCIMENTO, Samuel Pontes do. Ideologia constitucional e pluralismo produtivo. Revista da Faculdade UFMG, Número Esp. em Memória ao Prof. Washington Peluso Albino de Souza, p. 265-300, 2013.

COELHO, Luiz Fernando. Considerações sobre economia e planejamento no Direito Administrativo. In: ABUJAMRA JÚNIOR, João (Coord.). Direito Administrativo Aplicado e Comparado. t. I. São Paulo: Resenha Universitária, 1979. p. 141-165.

COMPARATO, Fábio Konder. A afirmação histórica dos direitos humanos. 3. ed., rev. e ampl. São Paulo: Saraiva, 2003.

. O indispensável Direito Econômico. In: Ensaios e Pareceres de Direito Empresarial. Rio de Janeiro: Forense, 1978. p. 453-472.

. Ordem econômica na Constituição Brasileira de 1988. Revista de Direito Público, São Paulo, v. 23, n. 93, p. 263-276, jan./mar. 1990.

CONTI, José Maurício; CARVALHO, André Castro. O Controle Interno na Administração Pública Brasileira: Qualidade do Gasto Público e Responsabilidade Fiscal. Revista de Direito Público, v. 8, n. 37, p. 201-220, jan./fev. 2011. Disponível em: $<$ https://www.portaldeperiodicos.idp.edu.br/ direitopublico/article/view/1845/1028>. Acesso em: 20 out. 2019.

DI PIETRO, Maria Sylvia Zanella. Direito administrativo. 27. ed. São Paulo: Atlas, 2014.

FARJAT, Gérard. Droit Économique. Paris: PUF, 1971.

FONROUGE, Carlos M. Giuliani. Derecho Financiero . 3. ed. Buenos Aires: Depalma, 1982.

FURTADO, Celso. Desenvolvimento e Subdesenvolvimento. 5. ed. Rio de Janeiro: Contraponto; Centro Internacional Celso Furtado, 2009.

Dialética do desenvolvimento. Rio de Janeiro: Fondo de Cultura, 1964.

. Teoria e Política do Desenvolvimento Econômico. 10. ed., rev. Rio de Janeiro: Paz e Terra, 2000 .

GELCER, Daniel Monteiro. Incentivos fiscais, desconcentração industrial e desenvolvimento regional. 2017. Tese (Doutorado em Direito) - Faculdade de Direito, Universidade de São Paulo, São Paulo, 2017. 
. Teoria Furtadiana de Desenvolvimento Econômico e a Ordem Econômica Constitucional Brasileira. 2010. Dissertação (Mestrado em Direito Econômico e Financeiro) - Universidade de São Paulo, São Paulo, 2010.

GIACOMONI, James. Orçamento público. 15. ed. São Paulo: Atlas, 2010.

GRAU, Eros Roberto. A ordem econômica na Constituição de 1988. 17. ed., rev. e atual. São Paulo: Malheiros, 2015.

. Elementos de direito econômico . São Paulo: Revista dos Tribunais, 1981.

1978.

Planejamento Econômico e Regra Jurídica. São Paulo: Revista dos Tribunais,

HARADA, Kiyoshi. Direito financeiro e tributário. 24. ed. São Paulo: Atlas, 2015.

HORVATH, Estevão. O Orçamento no século XXI: tendências e expectativas. Tese (Concurso de professor titular de Direito Financeiro) - Universidade de São Paulo, São Paulo, 2014.

INGROSSO, Giovanni. Corso di finanza pubblica. Napoli: Dott Eugenio Jovene, 1969.

INSTITUIÇÃO FISCAL INDEPENDENTE. Relatório de Acompanhamento Fiscal. n. 1. Brasília, fev. 2017. Disponível em: $<$ http://www2.senado.leg.br/bdsf/bitstream/handle/id/529484/RAF_

fev17_completo.pdf?sequence=1>. Acesso em: 16 nov. 2019.

IPEA. Instituto de Pesquisa Econômica Aplicada. Carta de Conjuntura, Brasília, n. 42, p. 112, $1^{\mathrm{o}}$ trimestre 2019. Disponível em: <http://www.ipea.gov.br/portal/images/stories/PDFs/ conjuntura/190219_cc42_politica_fiscal.pdf>. Acesso em: 17 nov. 2019.

IRTI, Natalino. L’ordine giuridico del mercato. Roma: Editori Laterza, 2001.

MARQUES NETO, Floriano Peixoto de Azevedo. Os grandes desafios do controle da Administração Pública. Fórum de Contratação e Gestão Pública - FCGP, Belo Horizonte, v. 9, n. 100, p. 7-30, abr. 2010.

. Os grandes desafios do controle da Administração Pública. In: MODESTO, Paulo (coord.). Nova Organização Administrativa Brasileira. Belo Horizonte: Fórum, 2009. p. 195-226.

MASSONETTO, Luís Fernando. O direito financeiro no capitalismo contemporâneo: a emergência de um novo padrão normativo. 2006. Tese (Doutorado em Direito Econômico e Financeiro) - Faculdade de Direito da USP, Universidade de São Paulo, São Paulo, 2006.

MATIAS-PEREIRA, José. Finanças públicas: a política orçamentária no Brasil. 5. ed. São Paulo: Atlas, 2010.

MEDAUAR, Odete. Direito administrativo moderno. 18. ed. rev. e atual. São Paulo: Revista dos Tribunais, 2014.

MOREIRA, Vital. A Ordem Jurídica do Capitalismo. Coimbra: Centelha, 1978. 
MUSGRAVE, Richard. Teoria das finanças públicas: um estudo da economia governamental. v. 1. São Paulo: Atlas; Brasília: INL, 1973.

; MUSGRAVE, Peggy. Finanças públicas: teoria e prática. Rio de Janeiro: Campus; São Paulo: Edusp, 1980.

NUSDEO, Fábio. Curso de economia: introdução ao direito econômico. 3. Ed. São Paulo: Revista dos Tribunais, 2001.

OLIVEIRA, Francisco de. Noiva da Revolução, Elegia para uma Re(li)gião. São Paulo: Boitempo, 2008.

OLIVEIRA, Regis Fernandes de. Curso de Direito Financeiro. 4. ed. São Paulo: Revista dos Tribunais, 2011. 2005.

. Deve o orçamento ser cumprido? Jus Navegandi, Teresina, v. 9, n. 672, 8 maio

; HOVART, Estevão; TAMBASCO, Teresa Cristina Castrucci. Manual de Direito Financeiro. São Paulo: Revista dos Tribunais, 1990.

REZENDE, Fernando. Finanças Públicas. São Paulo: Atlas, 1980.

RIBEIRO, Sheila Maria Reis. Controle Interno e Paradigma Gerencial. Brasília: ENAP, 1997.

RODRIK, Dani. Rescuing Economics from Neoliberalism. Massachusetts: Boston Review, 2007. Disponível em: <https://bostonreview.net/class-inequality/dani-rodrik-rescuingeconomics-neoliberalism>. Acesso em: 10 nov. 2019.

ROSA JÚNIOR, Luiz Emygdio Franco da. Manual de direito financeiro e direito tributário. 15. ed. Rio de Janeiro: Renovar, 2001.

ROSILHO, Andre Janjacomo. Controle da Administração Pública pelo Tribunal de Contas da União. 2016. Tese (Doutorado em Direito) - Faculdade de Direito, Universidade de São Paulo, São Paulo, 2016.

SAVY, Robert. Droit Public Économique. Paris: Dalloz, 1972.

SCAFF, Fernando Facury. A Constituição Econômica Brasileira em seus 15 anos. Revista de Direito Público da Economia, ano 1, no 03, jul/set, 2003.

SCHOUERI, Luís Eduardo. Normas tributárias indutoras e intervenção econômica. Rio de Janeiro: Forense, 2005.

SILVA, Gerson Augusto da. A política tributária como instrumento do desenvolvimento. 2. ed. Brasília: ESAF, 2009.

SILVA, José Afonso da. Orçamento-programa no Brasil. São Paulo: Revista dos Tribunais, 1973. 
NASCIMENTO, Carlos Valder do (Orgs.). Tratado de direito financeiro. v. 2. São Paulo: Saraiva, 2013.

SOUZA NETO, Cláudio Pereira de SOUZA. MENDONÇA, José Vicente Santos de. "Fundamentalização e Fundamentalismo na Interpretação do Princípio Constitucional da Livre Iniciativa" in Cláudio Pereira de Souza Neto e Daniel Sarmento (Coord.), A Constitucionalização do Direito: Fundamentos Teóricos e Aplicações Específicas, Rio de Janeiro, Lumen Juris, 2007, p. 740.

SOUZA, Washington Peluso Albino de. Primeiras linhas de Direito Econômico. 6. ed. São Paulo: LTr: 2005.

Teoria da constituição econômica. Belo Horizonte: Del Rey, 2002.

SPECK, Bruno Wilhelm. Inovação e rotina no Tribunal de Contas da União - o papel da instituição superior de controle financeiro no sistema político-administrativo do Brasil. São Paulo: Fundação Konrad Adenauer, 2000.

SURREY, Stanley S. The Tax Expenditure Concept and the Budget Reform Act of 1974. Boston College Law Review, v. 17, n. 7, p. 679-737, 1976.

TOLEDO, Gastão Alves de. O Direito Constitucional Econômico e sua Eficácia. Rio de Janeiro: Renovar, 2004.

TORRES, Heleno Taveira. Constituição financeira e o federalismo financeiro cooperativo equilibrado brasileiro. Revista de Direito Econômico e Financeiro, n. 5, 2014, p. 27.

TORRES, Ricardo Lobo. Curso de direito financeiro e tributário. 18. ed. Rio de Janeiro: Renovar, 2011.

O Tribunal de Contas e o controle da legalidade, economicidade e legitimidade. Revista do TCE-RJ, Rio de Janeiro, n. 22, p. 37-44, jul./1991.

- Tratado de direito constitucional financeiro e tributário - O orçamento na Constituição. v. 5, 3. ed. Rio de Janeiro: Renovar, 2008.

- Tratado de Direito constitucional, financeiro e tributário - Constituição financeira, sistema tributário e estado fiscal. v. 1. Rio de Janeiro: Renovar, 2009.

VALENTE, Patricia Rodrigues Pessôa. Avaliação de Impacto Regulatório: uma ferramenta à disposição do Estado. 2000. Dissertação (Mestrado em Direito) - Faculdade de Direito, Universidade de São Paulo, São Paulo, 2010.

VIDIGAL, Geraldo de Camargo. Fundamentos do direito financeiro. São Paulo: Revista dos Tribunais, 1973.

Teoria Geral do Direito Econômico. São Paulo: Revista dos Tribunais, 1997.

VILLEGAS, Hector. Curso de finanzas, derecho financiero y tributario. 7. ed., ampl. y actual. Buenos Aires: Depalma, 2001. 
XAVIER, António Lobo. O orçamento como lei - contributo para a compreensão de algumas especificidades do direito orçamental português. Boletim de Ciências Económicas, v. 33, p. 193-235, 1990. 


\section{BIBLIOGRAFIA PESQUISADA}

ANDRADE, José Maria Arruda de. A Constituição brasileira e as considerações teleológicas na hermenêutica constitucional. In: SOUZA NETO, Cláudio Pereira de; SARMENTO, Daniel; BINENBOJM, Gustavo (Orgs.). Vinte anos da Constituição Federal de 1988. Rio de Janeiro: Lumen Juris, 2009. p. 323-340.

Como Entender os Benefícios Fiscais, Financeiros e Creditícios. Consultor Jurídico, São Paulo: Conjur, 9 jul. 2017. Disponível em: <https://www.conjur.com.br/2017jul-09/estado-economia-cono-entender-beneficios-tributarios-financeiros-crediticios $>$. Acesso em: 01 out. 2019.

É Fundamental Repensar Política Econômica que se Vale de Tributos. Consultor Jurídico, São Paulo: Conjur, 17 abr. 2016. Disponível em: <https://www.conjur.com.br/2016abr-17/estado-economia-politica-economica-vale- tributos-repensada $>$. Acesso em: 01 out. 2019.

Economicização do Direito Concorrencial. São Paulo: Quartier Latin, 2014.

- Legislador Tributário Precisa de Mais Clareza pra Criar Segurança Jurídica. Consultor Jurídico, São Paulo: Conjur, 15 maio 2016. Disponível em: $<$ https://www.conjur.com.br/2016-mai-15/estado-economia-legislador-tributario- clarezaseguranca-juridica $>$. Acesso em: 01 out. 2019.

. Reforma tributária não pode ignorar diferenças entre as regiões. Consultor Jurídico, São Paulo: Conjur, 19 maio 2019. Disponível em: <https://www.conjur.com.br/2019-mai19/reforma-tributaria-nao-ignorar-diferencas- entre-regioes $>$. Acesso em: 01 out. 2019.

ARAÚJO, Tânia Bacelar. Ensaios sobre o desenvolvimento brasileiro: Heranças e urgências. Rio de Janeiro: Revan, 2000.

ASSONI FILHO, Sérgio; BLIACHERIENE, Ana Carla; ANDRADE, Cesar Augusto Seijas de. Dívida Pública. In: OLIVEIRA, Regis Fernandes; HORVATH, Estevão; CONTI, José Maurício; SCAFF, Fernando Facury (Coords.). Lições de Direito Financeiro. São Paulo: Revista dos Tribunais, 2016. p. 95-118.

BARROS, Maurício. Orçamento e discricionariedade. In: CONTI, José Maurício; SCAFF, Fernando Facury (Coords.). Orçamentos Públicos e Direito Financeiro. São Paulo: Revista dos Tribunais, 2011. p. 975-1007.

BERCOVICI, Gilberto. Constituição Econômica e Dignidade da Pessoa Humana. Revista da Faculdade de Direito. Universidade de São Paulo, v. 102, p. 457-467, 2007.

Estado, Soberania e Projeto Nacional de desenvolvimento: breves indagações sobre a constituição de 1988. Revista Latino-Americana de Estudos Constitucionais, n. 1, p. 559569, jan./jun. 2003.

Os Princípios Estruturantes e o Papel do Estado. In: CARDOSO JR., José Celso. A Constituição Brasileira de 1988 Revisitada: recuperação histórica e desafios atuais das políticas públicas nas áreas econômica e social. v. 1. Brasília: Ipea, 2009. p. 255-291. 
BIELSCHOWSKY, Ricardo. Formação Econômica do Brasil: uma obra-prima do estruturalismo cepalino. Revista de Economia Política, v. 9, n. 4, p. 38-55, out./dez. 1989.

BONAVIDES, Paulo. Curso de Direito Constitucional. 11. ed. São Paulo: Malheiros, 2000.

BORGES, José Souto Maior. Introdução ao Direito Financeiro. 2. ed. São Paulo: Max Limonad, 1998.

BRASIL. Banco Nacional de Desenvolvimento Econômico e Social. Disponível em: $<$ https://www.bndes.gov.br>. Acesso em: 01 out. 2019.

Tribunal de Contas da União. Disponível em: $<$ https://portal.tcu.gov.br/inicio/>. Acesso em: 01 out. 2019.

BRESSER-PEREIRA, Luiz Carlos. Celso Furtado: o desenvolvimento como missão. SABOIA, João; CARVALHO, Fernando J. Cardim de (Orgs.). Celso Furtado e o Século XX. Barueri: Manole, 2007. p. 63-80.

BULOS, Uadi Lammêgo. Curso de Direito Constitucional. 4. ed. São Paulo: Saraiva, 2009.

CARVALHO, André de Castro; LOCHAGIN, Gabriel Loretto; SILVEIRA, Francisco Secaf A. Orçamento Público. In: OLIVEIRA, Regis Fernandes; HORVATH, Estevão; CONTI, José Maurício; SCAFF, Fernando Facury (Orgs.). Lições de Direito Financeiro. São Paulo: Revista dos Tribunais, 2016. p. 67-94.

COMPARATO, Fábio Konder. Planejar o desenvolvimento: a perspectiva institucional. In: Para viver a democracia. São Paulo, Brasiliense, 1989. p. 83-123.

CONTI, José Mauricio (Coord.). Orçamentos públicos. A Lei 4.320 comentada. 2. ed. São Paulo: Revista dos Tribunais, 2010.

Direito Financeiro na Constituição de 1988. São Paulo: Oliveira Mendes, 1998.

Dívida pública e responsabilidade fiscal no federalismo brasileiro. In: SCHOUERI, Luís Eduardo (Coord.) Direito Tributário. Estudos em homenagem a Alcides Jorge Costa. v. 2. São Paulo: Quartier Latin, 2003. p. 1077-1094.

DIMOULIS, Dimitri. Positivismo, moralismo, e pragmatismo na interpretação do direito constitucional. Revista dos Tribunais, v. 88, n. 769, p. 11-27, nov. 1999.

FIGUEIREDO, Carlos Maurício Cabral. Lei de Responsabilidade Fiscal: o resgate do planejamento governamental. In: FIGUEIREDO, Carlos Maurício; NÓBREGA, Marcos. Lei de Responsabilidade Fiscal: aspectos polêmicos. Belo Horizonte: Fórum, 2006. p. 135-151.

FIORI, José Luís. O Vôo da coruja: para reler o desenvolvimento brasileiro. Rio de Janeiro: Record, 2003.

Sistema mundial: império e pauperização para retomar o pensamento crítico latinoamericano. FIORI, José Luís; MEDEIROS, Carlos (Orgs.). Polarização Mundial e Crescimento. Petrópolis: Vozes, 2001. p. 39-59. 
FURTADO, Celso. Brasil: a construção interrompida. 2. ed. Rio de Janeiro: Paz e Terra, 1992.

. Formação econômica do Brasil. 34. ed. São Paulo: Companhia das Letras, 2007.

. Introdução ao desenvolvimento: enfoque histórico-estrutural. 3. ed. Rio de Janeiro: Paz e Terra, 2000.

. O Mito do Desenvolvimento Econômico. Rio de Janeiro: Paz e Terra, 1996.

. Um projeto para o Brasil. 5. ed. Rio de Janeiro: Saga, 1969.

GOMES, Emerson Cesar da Silva. O Direito dos Gastos Públicos no Brasil. São Paulo: Almedina, 2015.

GRAU, Eros Roberto. Ensaio e discurso sobre a interpretação/aplicação do direito. 5. ed. São Paulo: Malheiros, 2009.

. O direito posto e o direito pressuposto. São Paulo: Malheiros, 2000.

HERMANN, Jennifer. A macroeconomia da dívida pública: notas sobre o debate teórico e a experiência brasileira recente. Dilemas da dívida. Rio de Janeiro: Fundação Konrad Adenauer, nov. 2002 (Cadernos Adenauer III, n. 4).

HIRSCHMAN, Albert Otto. Política econômica na América Latina. Rio de Janeiro: Fundo de Cultura, 1963.

HUNT, Emery Kay. História do Pensamento Econômico: Uma Perspectiva Crítica. 2. ed. Rio de Janeiro: Elsevier, 2005.

IANNI, Octavio. Estado e Planejamento Econômico no Brasil. 5. ed. Rio de Janeiro, Civilização Brasileira, 1991.

JARACH, Dino. Finanzas Públicas y Derecho Tributario. Buenos Aires: Cantagallo, 1993.

JÈZE, Gaston. Cours de science des finances et de législation financière française. Paris: Marcel Giard, 1922.

LAPATZA, José Juan Ferreiro. Dívida Pública. Revista de Direito Público, São Paulo, n. 84, p. 122-127, out./dez. 1987.

LARENZ, Karl. Metodologia da ciência do direito. 4. ed. Tradução de José Lamego. Lisboa: Fundação Calouste Gulbenkian, 2005.

MEDAUAR, Odete. Controle da Administração Pública. 2. ed. São Paulo: Revista dos Tribunais, 2012.

MONCADA, Luís S. Cabral de. Direito económico. 3. ed. rev. e atual. Coimbra, Coimbra Editora, 2000.

MOREIRA NETO, Diogo de Figueiredo. O Estado e a economia na Constituição de 1988. Revista de Informação Legislativa, v. 26, n. 102, p. 5-20, abr./jun. 1989. 
MOREIRA, Vital. Economia e Constituição: Para o Conceito de Constituição Econômica. 2. ed. Coimbra: Coimbra, 1974.

MYRDAL, Gunnar. Teoria econômica e regiões subdesenvolvidas. Rio de Janeiro: Saga, 1972.

NEVES, Antônio Castanheira. Redução Política do Pensamento Metodológico-Jurídico. Digesta. v. 2. Coimbra: Coimbra, 1995.

NEVES, Marcelo. A constitucionalização simbólica. São Paulo: Acadêmica, 1994.

A Interpretação Jurídica no Estado Democrático de Direito. In: GRAU, Eros; GUERRA FILHO, Willis S. (Orgs.). Direito Constitucional: estudos em homenagem a Paulo Bonavides. São Paulo: Malheiros, 2001. p. 356-376.

Constitucionalização simbólica e desconstitucionalização fática: mudança simbólica da Constituição e permanência das estruturas reais de poder. Revista Trimestral de Direito Público, São Paulo: Malheiros, v. 12, p. 156-67, 1995.

NOGUEIRA, Ruy Barbosa. Curso de direito tributário. São Paulo: Saraiva, 1995.

NUNES, António José Avelãs. Noção e objecto da economia política. Coimbra: Almedina, 1996.

Teoria económica e desenvolvimento económico: a controvérsia monetarismo/estruturalismo na américa latina. Lisboa: Caminho, 1988.

Uma Introdução à Economia Política. São Paulo: Quartier Latin, 2007.

OLIVEIRA, Francisco de. A Navegação Venturosa: ensaios sobre Celso Furtado. São Paulo: Boitempo, 2003.

. Celso Furtado: formação econômica do Brasil. In: MOTA, Lourenço Dantas (Org.). Introdução ao Brasil: um banquete nos trópicos. v. 1, 3. ed. São Paulo: SENAC, 2001.

. Para retomar a construção interrompida (Prefácio). In: SABOIA, João; CARVAlHO, Fernando J. Cardim de (Org.). Celso Furtado e o Século XX. Barueri: Manole, 2007. p. xvii-xx.

OLIVEIRA, Regis Fernandes de. Gastos públicos. São Paulo: Revista dos Tribunais, 2012.

PERROUX, François. A Economia do Século XX. Lisboa: Morais, 1967.

Ensaio sobre a filosofia do novo desenvolvimento. Lisboa: Fundação Calouste Gulbenkian, 1987.

PIÉDELIÈVRE, Alain et Marie-Claire. Droit du crédit. Paris: PUF, 1985.

POLLARI, Nicolò. Scienza delle Finanze. Roma: Laurus Robuffo, 1995.

PIRES, Adilson Rodrigues. Incentivos Fiscais e o Desenvolvimento Econômico. In: SCHOUERI, Luís Eduardo (Coord.). Direito Tributário. v. 2. São Paulo: Quartier Latin, 2003, p. 1110-1124. 
PRADO JR., Caio. História e Desenvolvimento. 3. ed. São Paulo: Brasiliense, 1989.

. História Econômica do Brasil. 32. ed. São Paulo: Brasiliense, 1985.

PREBISCH, Raúl. Dinâmica do desenvolvimento Latino-Americano. Mar del Plata: Fundo de Cultura, 1968.

O desenvolvimento econômico da América Latina e alguns de seus problemas principais. 1949. In: BIELSCHOWSKY, Ricardo (Org.). Cinquenta anos do pensamento da Cepal. Rio de Janeiro: Record, 2000. p. 69-136.

REGO, José Marcio (Org.). Retórica na economia. São Paulo: Edições 34, 1996.

RISTER, Carla Abrantkoski. Direito ao desenvolvimento: antecedentes, significados e consequências. 2003. Tese (Doutorado em Direito Econômico e Financeiro) - Faculdade de Direito da Universidade de São Paulo, São Paulo, 2003.

RODRIGUEZ, José Rodrigo (Org.). O Novo Direito e Desenvolvimento: Presente, Passado e Futuro. Textos selecionados de David M. Trubek. São Paulo: Saraiva, 2009.

SALOMÃO FILHO, Calixto. Direito como instrumento de transformação social e econômica. Revista de Direito Público da Economia, Belo Horizonte, v. 1, n. 1, p. 15-44, 2003.

SANTI, Eurico Marcos Diniz de (Coord.). Curso de direito tributário e finanças públicas: do fato à norma, da realidade ao conceito jurídico. São Paulo: Saraiva, 2008.

SCHUMPETER, Joseph A. Teoria do desenvolvimento econômico. Tradução: Laura Schlaepfer. Rio de Janeiro: Fundo de Cultura, 1961.

SILVA, José Afonso da. Curso de direito constitucional positivo. São Paulo: Malheiros, 2010 .

SILVA. Sandoval Alves da. Direitos Sociais. Leis orçamentárias como instrumento de implementação. Curitiba: Juruá, 2007.

SOUZA NETO, Cláudio Pereira de; SARMENTO, Daniel. A Constitucionalização do Direito: fundamentos teóricos e aplicações práticas. Rio de Janeiro: Lumen Juris, 2007.

SOUZA, Washington Peluso Albino de. Direito Econômico. São Paulo: Saraiva, 1980.

TAVARES, Maria da Conceição (Org.). Celso Furtado e o Brasil. São Paulo: Fundação Perseu Abramo, 2000.

TORRES, Heleno Taveira. Direito Constitucional Financeiro. Teoria da Constituição Financeira. São Paulo: Revista dos Tribunais, 2014.

TORRES, Ricardo Lobo. O direito ao mínimo existencial. Rio de Janeiro: Renovar, 2009.

TROTABAS, Louis. Finances Publiques. 3. ed. Paris: Dalloz, 1969.

VASCONCELlOS, Roberto França (Org.). Política Fiscal. São Paulo: Saraiva; Direito GV, 2009 (Série GV-Law). 


\section{ANEXO - Demonstrativo de Benefícios Creditícios e Financeiros $2018^{256}$}

\begin{tabular}{|c|c|c|c|c|c|c|c|c|c|}
\hline DISCRIMINAÇÃ̃O & Tipologia & 2003 & 2004 & 2005 & 2006 & 2007 & 2008 & 2009 & 2010 \\
\hline Benefícios Financeiros & Explícito & $\mathbf{5 . 7 1 8 . 7 2 7}$ & 2.798 .988 & 7.676 .241 & 6.981 .278 & 9.418 .768 & 7.424.614 & 9.377 .292 & 3.751 .973 \\
\hline Programa de Sustentação do Investimento - PSI & Explícito & & & & & & & & \\
\hline $\begin{array}{l}\text { Subvenção à Comercialização de Óleo Diesel Combustível de } \\
\text { Uso Rodoviário }\end{array}$ & Explícito & & & & & & & & \\
\hline Minha Casa Minha Vida - MCMV & Explícito & & & & & & & 1.571 .858 & 1.571 .804 \\
\hline PRONAF (Equalização) & Explícito & 569.375 & 609.211 & 762.290 & 1.088 .674 & 566.319 & 797.508 & 767.870 & 323.856 \\
\hline Fundo de Compensação das Variações Salariais - FCVS & Explícito & 532.841 & 8.169 .180 & 130.097 & 1.028 .756 & 3.514 .014 & 2.934 .909 & 693.585 & 6.497 .732 \\
\hline Operações de Investimento Rural e Agroindustrial & Explícito & 259.185 & 342.325 & 267.541 & 484.918 & 27.492 & 28.369 & $(72.318)$ & (339) \\
\hline Subv. de Energia Elétrica da Subclasse Baixa Renda & Explícito & - & 1.099 .437 & 1.307 .457 & 1.400 .115 & 946.829 & 1.339 .974 & 1.719 .969 & 1.674 .817 \\
\hline Custeio Agropecuário & Explícito & 356.221 & 106.603 & 204.225 & 341.561 & 956.679 & 446.154 & 197.961 & 488.840 \\
\hline Subvenção Econômica ao Prêmio do Seguro Rural - PSR & Explícito & - & 6 & 2.315 & 31.122 & 60.962 & 157.545 & 178.507 & 198.278 \\
\hline PESA (Explícito) & Explícito & 182.091 & 135.677 & 300.874 & 197.200 & 216.358 & 237.657 & 247.411 & 99.431 \\
\hline PROEX (Equalização) & Explícito & 917.301 & 483.763 & 608.717 & 448.810 & 382.918 & 307.124 & 394.295 & 231.731 \\
\hline FUNCAFÉ (Equalização) & Explícito & & & & & 2.606 & 23.680 & 52.951 & 82.715 \\
\hline AGF e Estoques Estratégicos & Explícito & 756.393 & 216.961 & 855.283 & 249.973 & $(124.343)$ & $(157.099)$ & 2.411 .392 & 1.115 .619 \\
\hline Empréstimos do Governo Federal - EGF & Explícito & 16.438 & 5.411 & 6.706 & 3.289 & 30.914 & 7.770 & 11.507 & 88.683 \\
\hline FDNE (Equalização) & Explícito & & & & & & & & \\
\hline Programa de Apoio ao Setor Sucroalcooleiro - PASS & Explícito & 8.660 & 39.282 & 20.065 & - & - & - & - & - \\
\hline Garantia e Sustentação de Preços & Explícito & 25.770 & 14.611 & 235.963 & 906.106 & 1.181 .122 & 935.916 & 925.646 & 1.359 .018 \\
\hline Revitaliza & Explícito & & & & & & & 58.673 & - \\
\hline FDCO (Equalização) & Explícito & & & & & & & & \\
\hline Garantia e Sustentação de Preços da Agric. Familiar & Explícito & & & & & & & & \\
\hline Viver sem Limite - PCD & Explícito & & & & & & & & \\
\hline
\end{tabular}

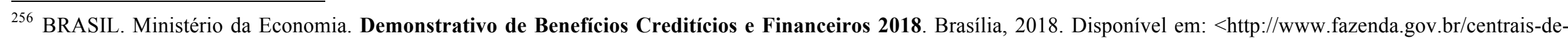
conteudos/publicacoes/demonstrativos-financeiros-e-crediticios/beneficios-financeiros-e-crediticios/demonstrativo-de-beneficios-financeiros-e-crediticios-2018>. Acesso em: 16 nov. 2019. 


\begin{tabular}{|c|c|c|c|c|c|c|c|c|c|}
\hline DA (Equalização) & Explícito & & & & & & & & \\
\hline Subv. ao Preço do Óleo de Embarcações Pesqueiras & Explícito & 2.800 & 7.401 & 6.250 & 19.435 & 25.500 & 20.479 & 21.785 & 19.787 \\
\hline Securitização Agrícola & Explícito & 1.928 .406 & 1.242 .924 & 2.699 .377 & 486.922 & 1.497 .506 & - & - & - \\
\hline RECOOP (Equalização) & Explícito & & & & & & & 948 & - \\
\hline Recuperação da Lavoura Cacaueira (Equalização) & Explícito & 590 & 1.134 & 1.185 & 1.106 & 292 & 9.304 & 836 & - \\
\hline Investimentos na Região Centro-Oeste (equalização FAT) & Explícito & - & 52 & 4.213 & 8.447 & 6.831 & 3.089 & 1.097 & - \\
\hline Programa de MPO - Programa Crescer & Explícito & & & & & & & & \\
\hline Financ. em Projetos de Habitação Popular & Explícito & 158.545 & 324.369 & 263.683 & 284.846 & 126.769 & 332.234 & 193.318 & - \\
\hline Subv. aos Produtores de Borracha Natural & Explícito & 4.111 & 641 & - & - & - & - & - & - \\
\hline Benefícios Creditícios & Implícito & 11.616.697 & 12.727 .262 & 25.024.193 & 16.457.031 & 8.258 .363 & 16.378 .028 & 13.672.831 & 15.166 .723 \\
\hline Empréstimos da União ao BNDES & Implícito & & & & & & 17.776 & 4.576 .871 & 8.469 .246 \\
\hline Fundo de Amparo ao Trabalhador - FAT & Implícito & 3.938 .423 & 6.971 .591 & 11.937 .912 & 9.305 .165 & 5.195 .308 & 3.813 .958 & $(857.546)$ & $(1.505 .722)$ \\
\hline Fundos Constitucionais de Financ. - FNE, FNO e FCO & Implícito & 3.195 .025 & 2.829 .898 & 10.163 .259 & 4.254 .792 & 4.117.308 & 5.552 .053 & 5.364 .761 & 6.192 .908 \\
\hline Fundo Financiamento Estudantil - FIES & Implícito & 304.167 & 212.580 & 304.381 & 156.770 & 304.739 & 1.740 .429 & 589.000 & 986.179 \\
\hline Fundo da Marinha Mercante - FMM & Implícito & 345.784 & 432.721 & 458.763 & 553.958 & 471.613 & 1.314 .572 & 3.671 & $(5.143)$ \\
\hline PROER & Implícito & 2.187 .641 & 1.081 .778 & 1.116 .792 & 1.393 .937 & $(2.518 .252)$ & $(1.506 .802)$ & 2.925 .886 & $(347.763)$ \\
\hline FDNE (Financiamento) & Implícito & & & & & & 74.440 & 4.866 & 117.955 \\
\hline FUNCAFÉ (Financiamento) & Implícito & 270.166 & 191.672 & 254.374 & 189.397 & 173.301 & 357.568 & 460.411 & 329.891 \\
\hline PROEX (Financiamento) & Implícito & 455.262 & 146.011 & 300.369 & 103.460 & $(148.779)$ & $(190.668)$ & $(348.430)$ & $(336.769)$ \\
\hline Fundo de Terras e da Reforma Agrária - Banco da Terra & Implícito & 73.218 & 131.794 & 138.251 & 156.932 & 156.182 & 242.198 & 135.907 & 319.692 \\
\hline PESA (Implícito) & Implícito & & & & & & & & 198.150 \\
\hline FNDCT & Implícito & & & & & & 314.792 & 220.633 & 169.184 \\
\hline PRONAF (Financiamento) & Implícito & 409.029 & 513.040 & 51.801 & 144.593 & 334.175 & 269.671 & 136.759 & $(268.166)$ \\
\hline FDCO (Financiamento) & Implícito & & & & & & & & \\
\hline FGPC & Implícito & 49.759 & 8.423 & 31.261 & 15.298 & 28.339 & 6.887 & $(11.640)$ & 6.884 \\
\hline Recuperação da Lavoura Cacaueira (Financiamento) & Implícito & 4.144 & 2.499 & 1.623 & 10.048 & 1.293 & 1.292 & 769 & 826 \\
\hline RECOOP (Financiamento) & Implícito & 74.621 & 58.008 & 73.199 & 19.404 & 20.759 & 27.591 & 13.629 & 10.112 \\
\hline FRD & Implícito & 43.019 & 20.407 & 12.725 & 29.409 & 24.224 & 21.416 & 6.558 & 9.300 \\
\hline FDA (Financiamento) & Implícito & & & & & & (31.624) & 58.244 & 39.884 \\
\hline
\end{tabular}


Fundo de Garantia à Exportação - FGE

Securitização Agrícola (implícito)

Fundo Nacional de Desenvolvimento - FND

\section{Benefícios Tributários}

SIMPLES Nacional

Zona Franca de Manaus e Áreas de Livre Comércio

Rendimentos Isentos e Não Tributáveis - IRPF

Entidades Sem Fins Lucrativos - Imunes / Isentas

Agricultura e Agroindústria - Desoneração Cesta Básica

Deduções do Rendimento Tributável - IRPF

Desoneração da Folha de Salários

Benefícios do Trabalhador

Poupança e Letra imobiliária Garantida

Medicamentos, Produtos Farmacêuticos e Equipamentos Médicos

Desenvolvimento Regional

Programa de Inclusão Digital

Informática e Automação

Setor Automotivo

Pesquisas Científicas e Inovação Tecnológica

REIDI

Olimpíada

Financiamentos Habitacionais

Embarcações e Aeronaves

MEI - Microempreendedor Individual

Transporte Coletivo

Cultura e Audiovisual

Álcool

PROUNI

\begin{tabular}{|c|c|c|c|c|c|c|c|c|}
\hline Implícito & & & & & & 4.194 .083 & $(3.028)$ & 779.263 \\
\hline Implícito & & & & & & & & \\
\hline Implícito & 266.438 & 126.841 & 179.483 & 123.868 & 98.152 & 158.395 & 395.509 & 812 \\
\hline Implícito & 34.539.338 & 35.826 .350 & 43.401 .962 & 65.397 .519 & 88.628.908 & 99.197.209 & 116.097 .994 & 135.860 .977 \\
\hline Implícito & 8.822 .498 & 12.622 .452 & 13.389 .577 & 15.055 .925 & 17.510 .104 & 18.996 .013 & 30.448 .690 & 36.314 .876 \\
\hline Implícito & 3.643 .134 & 3.671 .013 & 4.612 .080 & 11.228 .749 & 12.547 .907 & 14.809 .371 & 13.182 .330 & 17.257 .273 \\
\hline Implícito & 6.035 .811 & 2.451 .940 & 2.953 .521 & 3.949 .482 & 10.936 .400 & 11.013 .151 & 11.252 .044 & 12.315 .497 \\
\hline Implícito & 2.937 .469 & 5.430 .628 & 6.918 .863 & 5.273 .434 & 5.376 .441 & 5.904 .244 & 11.926 .922 & 13.450 .081 \\
\hline Implícito & 1.777 .634 & 1.860 .580 & 1.627 .710 & 4.466 .134 & 6.570 .261 & 7.328 .216 & 9.788 .859 & 9.879 .543 \\
\hline Implícito & 3.084 .505 & 2.561 .786 & 2.972 .688 & 3.159 .453 & 8.913 .399 & 10.273 .607 & 9.197 .710 & 9.488 .758 \\
\hline Implícito & - & - & - & - & - & - & - & - \\
\hline Implícito & 158.813 & 1.079 .107 & 2.042 .110 & 4.579 .562 & 4.330 .416 & 4.535 .179 & 4.950 .751 & 5.711 .209 \\
\hline Implícito & - & 5.178 & 4.936 & 652.205 & 2.345 .571 & 2.830 .854 & 2.976 .136 & 3.447 .350 \\
\hline Implícito & 847.893 & 964.560 & 1.398 .146 & 3.958 .468 & 2.875 .891 & 3.091 .655 & 3.455 .615 & 3.613 .704 \\
\hline Implícito & 2.303 .383 & 1.531 .325 & 2.187 .266 & 4.189 .466 & 4.286 .723 & 4.366 .265 & 4.105 .345 & 5.845 .638 \\
\hline Implícito & - & - & - & 625.726 & 1.005 .244 & 1.369 .000 & 1.262 .070 & 1.293 .844 \\
\hline Implícito & 1.530 .000 & 823.020 & 1.369 .063 & 2.038 .482 & 2.755 .400 & 3.261 .371 & 3.103 .252 & 3.570 .760 \\
\hline Implícito & 753.183 & 882.288 & 1.056 .464 & 768.733 & 1.523 .482 & 1.946 .288 & 1.716 .024 & 1.996 .615 \\
\hline Implícito & - & 228.112 & 368.683 & 767.402 & 1.545 .573 & 2.731 .830 & 2.122 .134 & 2.498 .566 \\
\hline Implícito & - & - & - & - & - & 57.639 & 606.553 & 1.218 .041 \\
\hline Implícito & - & - & - & - & - & - & - & - \\
\hline Implícito & 136.945 & 130.657 & 159.491 & 137.680 & 264.383 & 869.581 & 494.328 & 809.277 \\
\hline Implícito & 217.834 & 214.039 & 228.775 & 633.231 & 984.309 & 976.289 & 871.103 & 766.083 \\
\hline Implícito & - & - & - & - & - & - & - & - \\
\hline Implícito & - & - & - & - & - & - & - & - \\
\hline Implícito & 357.135 & 239.051 & 403.266 & 917.887 & 1.107 .019 & 957.980 & 826.680 & 1.088 .957 \\
\hline Implícito & - & - & - & - & - & - & - & - \\
\hline Implícito & - & - & - & 215.890 & 348.766 & 434.174 & 530.599 & 578.116 \\
\hline
\end{tabular}




\begin{tabular}{|c|c|c|c|c|c|c|c|c|c|}
\hline Termoeletricidade & Implícito & - & 15.067 & 294.473 & 55.745 & 65.651 & 73.223 & 74.229 & 124.491 \\
\hline REPNBL-Redes & Implícito & - & - & - & - & - & - & - & - \\
\hline Petroquímica & Implícito & 159.106 & 237.880 & 615.177 & 341.388 & 358.083 & 422.764 & 274.803 & 350.281 \\
\hline Gás Natural Liquefeito & Implícito & - & - & - & - & - & - & - & - \\
\hline Incentivo à Formalização do Emprego Doméstico & Implícito & - & - & - & 158.573 & 227.317 & 260.831 & 292.683 & 343.070 \\
\hline Horário Eleitoral Gratuito & Implícito & 174.110 & 238.585 & 283.549 & 494.637 & 150.710 & 420.395 & 201.129 & 604.264 \\
\hline Fundos Constitucionais & Implícito & - & 53.154 & 55.185 & 105.282 & 109.954 & 197.883 & 221.370 & 263.664 \\
\hline Minha Casa, Minha Vida & Implícito & - & - & - & - & - & - & 12.421 & 298.050 \\
\hline Fundos da Criança e do Adolescente & Implícito & - & 71.920 & 51.625 & 192.059 & 252.837 & 224.162 & 200.300 & 259.033 \\
\hline Livros Técnicos e Científicos & Implícito & - & - & - & 159.689 & 185.149 & 215.066 & 231.589 & 276.588 \\
\hline $\begin{array}{l}\text { Aquisição de Automóveis - Taxistas e Portadores de } \\
\text { Deficiência (IPI e IOF) }\end{array}$ & Implícito & - & 100.477 & 43.327 & 113.886 & 138.460 & 175.869 & 91.424 & 190.256 \\
\hline Máquinas e Equipamentos - Cnpq & Implícito & 199.491 & 245.395 & 126.002 & 235.716 & 280.451 & 492.479 & 502.208 & 494.918 \\
\hline Rede Arrecadadora & Implícito & - & - & - & - & - & - & - & - \\
\hline PADIS & Implícito & - & - & - & - & - & - & - & - \\
\hline $\begin{array}{l}\text { Doações a Instituições de Ensino e Pesquisa e Entidades } \\
\text { Civis Sem Fins Lucrativos }\end{array}$ & Implícito & - & 59.853 & 107.726 & 122.268 & 155.972 & 151.374 & 95.601 & 161.739 \\
\hline Cadeira de Rodas e Aparelhos Assistivos & Implícito & - & - & - & - & - & 2.092 & 5.024 & 106.701 \\
\hline Dona de Casa & Implícito & - & - & - & - & - & - & - & - \\
\hline Incentivo ao Desporto & Implícito & - & 7.620 & - & - & 49.769 & 68.025 & 99.963 & 167.274 \\
\hline Seguro Rural & Implícito & - & - & - & - & - & 52.679 & 66.486 & 63.749 \\
\hline REPORTO & Implícito & - & - & - & 26.928 & 44.294 & 102.164 & 107.433 & 101.197 \\
\hline REPENEC & Implícito & - & - & - & - & - & - & - & - \\
\hline Investimentos em Infra-Estrutura & Implícito & - & - & - & - & - & - & - & - \\
\hline Motocicletas & Implícito & - & - & - & - & - & - & 86.907 & 100.059 \\
\hline RENUCLEAR & Implícito & - & - & - & - & - & - & - & - \\
\hline Fundos do Idoso & Implícito & - & - & - & - & - & - & - & - \\
\hline PRONON & Implícito & - & - & - & - & - & - & - & - \\
\hline Água Mineral & Implícito & - & - & - & - & - & - & - & - \\
\hline RETID & Implícito & - & - & - & - & - & - & - & - \\
\hline
\end{tabular}




\begin{tabular}{|c|c|c|c|c|c|c|c|c|c|}
\hline Biodiesel & Implícito & - & - & - & 471 & 8.895 & 18.049 & 12.533 & 26.351 \\
\hline Papel - Jornais e Periódicos & Implícito & - & - & - & 63.277 & 97.042 & 114.266 & 136.320 & 50.729 \\
\hline $\begin{array}{l}\text { TI e TIC - Tecnologia de Informação e Tecnologia da } \\
\text { Informação e da Comunicação }\end{array}$ & Implícito & - & - & - & - & - & - & 34.337 & 82.241 \\
\hline RECINE & Implícito & - & - & - & - & - & - & - & - \\
\hline Isenções a Imóveis Rurais (ITR) & Implícito & - & - & 19.654 & 23.100 & 25.295 & 24.395 & 25.587 & 26.877 \\
\hline Promoção de produtos e serviços brasileiros & Implícito & - & - & - & 3.749 & 4.112 & 5.858 & 3.624 & 16.623 \\
\hline Transporte Escolar & Implícito & - & - & - & - & - & 15.878 & 27.046 & 54.563 \\
\hline Pronas/PCD & Implícito & - & - & - & - & - & - & - & - \\
\hline Creches e Pré-Escolas & Implícito & - & - & - & - & - & - & - & - \\
\hline Indústria Cinematográfica e Radiodifusão & Implícito & - & - & - & 6.949 & 15.996 & 23.351 & 22.638 & 15.367 \\
\hline PATVD & Implícito & - & - & - & - & - & - & - & - \\
\hline Resíduos Sólidos & Implícito & - & - & - & - & - & - & - & - \\
\hline Evento Esportivo, Cultural e Científico & Implícito & - & - & - & - & - & - & - & - \\
\hline Aerogeradores & Implícito & - & - & - & - & - & - & - & - \\
\hline RETAERO & Implícito & - & - & - & - & - & - & - & - \\
\hline REIF & Implícito & - & - & - & - & - & - & - & - \\
\hline Vale-Cultura & Implícito & - & - & - & - & - & - & - & - \\
\hline Construção Civil & Implícito & - & - & - & 558.099 & 1.221 .069 & 342.869 & 455.192 & 538.696 \\
\hline PROUCA-REICOMP & Implícito & - & - & - & - & - & - & - & - \\
\hline Crédito Presumido & Implícito & - & - & - & - & - & - & - & - \\
\hline Lojas Francas & Implícito & 151.077 & - & - & - & - & - & - & - \\
\hline Empresas montadoras & Implícito & - & - & - & - & - & - & - & - \\
\hline Seguro de Vida e Congêneres (IOF) & Implícito & - & - & - & - & - & - & - & - \\
\hline Produtos Químicos e Farmacêuticos & Implícito & - & - & - & - & - & - & - & - \\
\hline Programa de Alimentação do Trabalhador - PAT (IRPJ) & Implícito & - & - & - & - & - & - & - & - \\
\hline RECOPA & Implícito & - & - & - & - & - & - & - & - \\
\hline PDTI/PDTA & Implícito & 100.100 & 53.100 & 62.100 & 102.834 & 2.416 & 1.313 & - & - \\
\hline $\begin{array}{l}\text { Deduções com Benefícios Previdenciários e Assistenciais } \\
\text { e FAPI (IRPJ) }\end{array}$ & Implícito & - & 43.171 & 47.195 & - & - & - & - & - \\
\hline
\end{tabular}




\begin{tabular}{|c|c|c|c|c|c|c|c|c|c|}
\hline Trem de Alta Velocidade & Implícito & - & - & - & - & - & - & - & - \\
\hline RECOM & Implícito & - & - & - & - & - & - & - & - \\
\hline Copa do Mundo & Implícito & - & - & - & - & - & - & - & - \\
\hline Empreendimentos Turísticos (IRPJ) & Implícito & - & 4.392 & 3.311 & - & - & - & - & - \\
\hline Equipamentos Desportivos & Implícito & - & - & - & - & - & - & 4 & 3 \\
\hline Telecomunicações em áreas rurais e regiões remotas & Implícito & - & - & - & - & - & - & - & - \\
\hline $\begin{array}{l}\text { Associações de Poupança e Empréstimos e Planos de } \\
\text { Poupança e Investimentos - PAIT }\end{array}$ & Implícito & - & - & - & - & - & - & - & - \\
\hline Bagagem (II e IPI vinculado à importação) & Implícito & 799.908 & - & - & - & - & - & - & - \\
\hline Material Promocional (II e IPI vinculado à importação) & Implícito & - & - & - & - & - & - & - & - \\
\hline Adicional ao Frete para Renovação da Marinha Mercante & Implícito & - & - & - & - & - & - & - & - \\
\hline Demais & Implícito & 349.309 & - & - & 14.958 & 8.148 & 39.515 & - & - \\
\hline TOTAL & & 51.874 .762 & 61.352 .599 & 76.102.396 & 88.835.828 & 106.306.039 & 122.999 .852 & \begin{tabular}{|l}
139.148 .117 \\
\end{tabular} & 164.779 .673 \\
\hline
\end{tabular}




\begin{tabular}{|c|c|c|c|c|c|c|c|c|c|}
\hline DISCRIMINAÇÃO & Tipologia & 2011 & 2012 & 2013 & 2014 & 2015 & 2016 & 2017 & 2018 \\
\hline Benefícios Financeiros & Explícito & 19.748.944 & 19.997 .321 & 20.556 .871 & 23.937.520 & 77.765 .599 & 36.710 .069 & 24.651.895 & 28.229.599 \\
\hline Programa de Sustentação do Investimento - PSI & Explícito & 428.976 & 751.661 & 121.859 & 110.745 & 30.283 .656 & 10.215 .700 & 7.908 .381 & 5.009 .503 \\
\hline $\begin{array}{l}\text { Subvenção à Comercialização de Óleo Diesel Combustível de } \\
\text { Uso Rodoviário }\end{array}$ & Explícito & & & & & & & & 4.816 .361 \\
\hline Minha Casa Minha Vida - MCMV & Explícito & 7.711 .737 & 11.251 .950 & 14.187.186 & 17.430 .722 & 20.709 .076 & 7.965 .285 & 3.617 .942 & 4.569 .488 \\
\hline PRONAF (Equalização) & Explícito & 2.199 .812 & 2.365 .232 & 1.714 .954 & 456.555 & 10.126 .167 & 5.369 .474 & 4.089 .266 & 2.886 .509 \\
\hline Fundo de Compensação das Variações Salariais - FCVS & Explícito & 5.526 .649 & 670.416 & 13.390 & - & 3.682 .005 & 3.565 .350 & 588.340 & 1.600 .876 \\
\hline Operações de Investimento Rural e Agroindustrial & Explícito & 23.595 & 65.536 & 332.126 & 70.805 & 2.499 .396 & 2.968 .999 & 2.175 .549 & 1.578 .154 \\
\hline Subv. de Energia Elétrica da Subclasse Baixa Renda & Explícito & 1.265 .622 & 1.597 .181 & 1.999 .041 & 2.277 .529 & 2.141 .884 & 2.267 .894 & 2.358 .347 & 2.424 .531 \\
\hline Custeio Agropecuário & Explícito & 917.361 & 1.316 .617 & 126.149 & 640.549 & 5.177 .368 & 1.820 .040 & 2.039 .097 & 1.141 .754 \\
\hline Subvenção Econômica ao Prêmio do Seguro Rural - PSR & Explícito & 253.452 & 318.168 & 411.275 & 410.581 & 559.778 & 782.536 & 519.899 & 377.887 \\
\hline PESA (Explícito) & Explícito & 442.884 & 161.597 & 300.359 & 325.098 & 300.851 & 622.746 & 195.660 & 909.622 \\
\hline PROEX (Equalização) & Explícito & 404.948 & 588.358 & 516.177 & 819.907 & 737.160 & 619.297 & 580.624 & 831.772 \\
\hline FUNCAFÉ (Equalização) & Explícito & 65.606 & 74.520 & 68.231 & 103.941 & 101.234 & 110.118 & 112.707 & 107.377 \\
\hline AGF e Estoques Estratégicos & Explícito & $(440.928)$ & $(66.265)$ & 37.231 & 453.917 & 157.040 & 108.471 & 108.685 & 471.907 \\
\hline Empréstimos do Governo Federal - EGF & Explícito & 76.716 & 173.702 & 85.620 & 7.620 & 300.954 & 81.196 & 74.049 & 53.560 \\
\hline FDNE (Equalização) & Explícito & & & & & 16.273 & 60.777 & 41.569 & 39.425 \\
\hline Programa de Apoio ao Setor Sucroalcooleiro - PASS & Explícito & - & 716 & - & - & 48.915 & 56.573 & 46.040 & 28.023 \\
\hline Garantia e Sustentação de Preços & Explícito & 829.374 & 441.283 & 152.341 & 449.946 & 514.967 & 49.967 & 162.591 & 424.501 \\
\hline Revitaliza & Explícito & 25.695 & 57.311 & 6.865 & 2.844 & 2.363 & 25.965 & 16.302 & 9.193 \\
\hline FDCO (Equalização) & Explícito & & & & & 238 & 6.199 & 2.946 & 3.140 \\
\hline Garantia e Sustentação de Preços da Agric. Familiar & Explícito & - & - & - & 2.689 & 4.897 & 5.795 & 4.870 & 9.555 \\
\hline Viver sem Limite - PCD & Explícito & - & 13 & 484 & 834 & 4.986 & 5.656 & 6.301 & 6.634 \\
\hline FDA (Equalização) & Explícito & & & & & - & 1.428 & 2.730 & 2.044 \\
\hline Subv. ao Preço do Óleo de Embarcações Pesqueiras & Explícito & 17.303 & 1.692 & 6.144 & 5.934 & 4.093 & 600 & - & 2.260 \\
\hline Securitização Agrícola & Explícito & - & - & - & - & - & - & - & 890.409 \\
\hline RECOOP (Equalização) & Explícito & - & - & - & - & - & - & - & - \\
\hline Recuperação da Lavoura Cacaueira (Equalização) & Explícito & 142 & 428 & - & - & - & - & - & 29.638 \\
\hline
\end{tabular}


Investimentos na Região Centro-Oeste (equalização FAT)

Programa de MPO - Programa Crescer

Financ. em Projetos de Habitação Popular

Subv. aos Produtores de Borracha Natural

\section{Benefícios Creditícios}

Empréstimos da União ao BNDES

Fundo de Amparo ao Trabalhador - FAT

Fundos Constitucionais de Financ. - FNE, FNO e FCO

Fundo Financiamento Estudantil - FIES

Fundo da Marinha Mercante - FMM

PROER

FDNE (Financiamento)

FUNCAFÉ (Financiamento)

PROEX (Financiamento)

Fundo de Terras e da Reforma Agrária - Banco da Terra

PESA (Implícito)

FNDCT

PRONAF (Financiamento)

FDCO (Financiamento)

FGPC

Recuperação da Lavoura Cacaueira (Financiamento)

RECOOP (Financiamento)

FRD

FDA (Financiamento)

Fundo de Garantia à Exportação - FGE

Securitização Agrícola (implícito)

Fundo Nacional de Desenvolvimento - FND

\section{Benefícios Tributários}

SIMPLES Nacional

\begin{tabular}{|c|c|c|c|c|c|c|c|c|}
\hline Explícito & - & - & - & - & - & - & - & \\
\hline Explícito & - & 227.206 & 477.439 & 367.304 & 392.298 & - & - & 5.479 \\
\hline Explícito & - & - & - & - & - & - & - & - \\
\hline Explícito & - & - & - & - & - & - & - & - \\
\hline Implícito & 32.150 .783 & 35.891.021 & 56.473.075 & 37.362 .928 & 51.018.549 & 78.597.370 & 59.516 .770 & $(6.870 .963)$ \\
\hline Implícito & 10.538 .243 & 12.343 .318 & 10.629 .385 & 21.272 .338 & 18.969 .019 & 29.146 .451 & 15.661 .666 & 5.029 .011 \\
\hline Implícito & 9.377 .615 & 10.597 .112 & 12.512 .172 & 4.718 .769 & 5.427 .771 & 15.871 .207 & 15.053 .384 & $(26.691 .041)$ \\
\hline Implícito & 7.666 .348 & 7.933 .379 & 8.240 .990 & 9.927 .086 & 12.583 .484 & 15.000 .506 & 13.396 .641 & 10.874 .828 \\
\hline Implícito & 16.091 & 520.062 & 590.693 & 1.839 .602 & 6.655 .221 & 11.434 .186 & 7.583 .296 & 4.773 .198 \\
\hline Implícito & 1.816 .395 & (239.863) & 3.592 .221 & 2.035 .608 & 2.257 .542 & 2.853 .479 & $(2.850 .893)$ & $(1.950 .413)$ \\
\hline Implícito & $(295.945)$ & 2.227 .524 & 17.373 .362 & 599.072 & 790.175 & 1.154 .094 & 1.049 .053 & 88.768 \\
\hline Implícito & 525.692 & 321.052 & 1.648 .704 & 628.682 & 588.698 & 671.005 & 470.772 & 199.001 \\
\hline Implícito & 302.300 & 266.118 & 137.683 & 96.449 & 460.580 & 577.582 & 389.971 & $(257.201)$ \\
\hline Implícito & 306.086 & 275.647 & 136.096 & 207.242 & 121.499 & 575.035 & 244.418 & 166.438 \\
\hline Implícito & 317.303 & 297.368 & 266.760 & 19.555 & 691.803 & 454.384 & 324.947 & 266.758 \\
\hline Implícito & 209.742 & 231.835 & 239.233 & 254.332 & 379.082 & 417.727 & 419.000 & - \\
\hline Implícito & 326.959 & 364.308 & 997.667 & $(4.132 .347)$ & 1.588 .234 & 377.895 & 4.932 .802 & 21.388 \\
\hline Implícito & 112.728 & 310.320 & 208.668 & 247.190 & 326.302 & 408.419 & 302.987 & 312.005 \\
\hline Implícito & & & & 15.161 & 17.058 & 46.947 & 80.894 & 28.149 \\
\hline Implícito & (14.013) & $(13.045)$ & $(26.141)$ & 22.444 & $(73.150)$ & 13.284 & 2.304 & (31.479) \\
\hline Implícito & 3.690 & 2.797 & 3.433 & 5.782 & 9.416 & 10.892 & 9.190 & 7.022 \\
\hline Implícito & 24.080 & 17.191 & - & 8.631 & 9.044 & 7.565 & 4.184 & 8 \\
\hline Implícito & 8.714 & 10.334 & 2.715 & 34.415 & (10.479) & 212 & 8.043 & $(5.868)$ \\
\hline Implícito & 90.227 & 70.964 & 344.818 & $(162.242)$ & 373.573 & $(200.585)$ & 641.419 & (229.159) \\
\hline Implícito & 818.528 & 354.601 & $(425.383)$ & $(274.842)$ & (146.323) & $(222.915)$ & 1.619 .149 & 527.624 \\
\hline Implícito & & & & & & & 173.544 & - \\
\hline Implícito & - & - & - & - & - & - & - & - \\
\hline Implícito & 152.440 .736 & 181.747 .128 & 223.310.467 & 256.234.392 & 269.993.560 & 264.686 .806 & 278.743.062 & 292.841.128 \\
\hline Implícito & 40.898 .617 & 53.534 .421 & 62.056 .609 & 67.697 .671 & 69.205 .527 & 69.780 .094 & 71.801 .591 & 74.818 .057 \\
\hline
\end{tabular}




\begin{tabular}{|c|c|c|c|c|c|c|c|c|c|}
\hline Zona Franca de Manaus e Áreas de Livre Comércio & Implícito & 18.964 .145 & 20.897 .120 & 23.608 .765 & 24.242 .405 & 23.231 .869 & 21.050 .606 & 21.803 .294 & 25.086 .260 \\
\hline Rendimentos Isentos e Não Tributáveis - IRPF & Implícito & 14.015 .024 & 15.301 .891 & 17.764 .533 & 20.154 .965 & 23.854 .738 & 27.289.519 & 30.592 .192 & 31.101 .196 \\
\hline Entidades Sem Fins Lucrativos - Imunes / Isentas & Implícito & 14.609 .994 & 17.173 .479 & 18.343 .092 & 20.716 .366 & 19.505.110 & 23.538 .691 & 26.247 .477 & 27.253 .835 \\
\hline Agricultura e Agroindústria - Desoneração Cesta Básica & Implícito & 11.480 .443 & 13.271 .730 & 18.493 .567 & 19.609 .928 & 21.700 .303 & 20.704 .357 & 21.888 .722 & 24.674 .594 \\
\hline Deduções do Rendimento Tributável - IRPF & Implícito & 10.644 .594 & 12.012 .167 & 12.905 .431 & 14.224 .558 & 15.353 .389 & 17.067 .709 & 19.132.517 & 19.657 .553 \\
\hline Desoneração da Folha de Salários & Implícito & - & 3.615 .694 & 12.284 .295 & 22.107 .296 & 25.199 .064 & 14.546 .630 & 13.704 .090 & 12.104 .743 \\
\hline Benefícios do Trabalhador & Implícito & 6.332 .073 & 7.362 .772 & 9.005 .236 & 9.623 .448 & 9.951 .624 & 10.922 .129 & 11.405 .923 & 11.956 .075 \\
\hline Poupança e Letra imobiliária Garantida & Implícito & 4.328 .072 & 4.351 .163 & 5.029 .334 & 6.448 .254 & 7.500 .894 & 7.785 .761 & 6.924 .919 & 5.146 .433 \\
\hline $\begin{array}{l}\text { Medicamentos, Produtos Farmacêuticos e Equipamentos } \\
\text { Médicos }\end{array}$ & Implícito & 3.576 .448 & 4.187 .920 & 4.337 .938 & 5.034 .384 & 6.619 .069 & 9.534 .980 & 13.586 .512 & 14.934 .844 \\
\hline Desenvolvimento Regional & Implícito & 6.205 .480 & 5.596 .649 & 5.746 .445 & 6.067 .023 & 5.899 .084 & 7.097 .651 & 7.420 .374 & 7.760 .626 \\
\hline Programa de Inclusão Digital & Implícito & 1.945 .023 & 2.993 .670 & 5.829 .877 & 5.922 .998 & 5.007 .198 & - & - & - \\
\hline Informática e Automação & Implícito & 3.771 .520 & 4.482 .200 & 4.934 .899 & 5.207 .255 & 5.022 .390 & 4.735 .712 & 5.034 .062 & 5.783 .271 \\
\hline Setor Automotivo & Implícito & 1.719 .201 & 1.255 .630 & 2.519 .386 & 3.760 .208 & 4.180 .933 & 5.085 .474 & 5.517 .447 & 5.377 .573 \\
\hline Pesquisas Científicas e Inovação Tecnológica & Implícito & 2.260 .715 & 2.659 .538 & 2.817 .848 & 3.011 .289 & 3.391 .988 & 2.803 .971 & 2.930 .364 & 3.072 .707 \\
\hline REIDI & Implícito & 1.359 .418 & 2.106 .847 & 2.217 .592 & 2.369 .830 & 2.492 .213 & 1.223 .355 & 1.420 .721 & 1.489 .248 \\
\hline Olimpíada & Implícito & - & - & 66.560 & 96.202 & 227.679 & 1.208 .203 & 20.554 & - \\
\hline Financiamentos Habitacionais & Implícito & 1.918 .700 & 1.443 .878 & 1.540 .048 & 1.989 .792 & 1.901 .472 & 1.493 .284 & 1.477 .736 & 1.804 .582 \\
\hline Embarcações e Aeronaves & Implícito & 942.734 & 1.061 .327 & 1.531 .317 & 1.737 .778 & 2.100 .242 & 2.157 .729 & 2.077 .655 & 2.404 .125 \\
\hline MEI - Microempreendedor Individual & Implícito & 199.808 & 500.536 & 786.448 & 990.866 & 1.404 .148 & 1.676 .101 & 2.060 .914 & 2.562 .106 \\
\hline Transporte Coletivo & Implícito & - & - & 746.490 & 1.414 .214 & 1.543 .038 & 530.573 & 560.743 & 587.790 \\
\hline Cultura e Audiovisual & Implícito & 1.215 .350 & 1.143 .468 & 1.219 .765 & 1.366 .852 & 1.491 .224 & 1.304 .198 & 1.361 .484 & 1.424 .159 \\
\hline Álcool & Implícito & - & - & 747.000 & 1.370 .000 & 1.466 .000 & 1.304 .269 & - & - \\
\hline PROUNI & Implícito & 564.546 & 758.423 & 1.057 .372 & 1.129 .961 & 1.730 .302 & 2.170 .886 & 2.283 .713 & 2.393 .865 \\
\hline Termoeletricidade & Implícito & 87.321 & 196.958 & 366.890 & 557.325 & 658.081 & 439.463 & 485.734 & 523.795 \\
\hline REPNBL-Redes & Implícito & - & - & - & 29.078 & 174.091 & 298.944 & - & - \\
\hline Petroquímica & Implícito & 423.237 & 545.236 & 1.166 .908 & 1.284 .371 & 855.579 & 584.135 & 394.292 & 510.551 \\
\hline Gás Natural Liquefeito & Implícito & 52.523 & 333.955 & 679.160 & 902.459 & 592.569 & 148.676 & 158.025 & 302.818 \\
\hline Incentivo à Formalização do Emprego Doméstico & Implícito & 378.360 & 469.533 & 525.080 & 574.165 & 594.032 & 558.358 & 586.913 & 603.019 \\
\hline
\end{tabular}




\begin{tabular}{|c|c|c|c|c|c|c|c|c|c|}
\hline Horário Eleitoral Gratuito & Implícito & 207.223 & 436.272 & 254.582 & 852.117 & 305.498 & 657.848 & 335.757 & 720.933 \\
\hline Fundos Constitucionais & Implícito & 472.785 & 417.220 & 352.258 & 460.060 & 526.780 & 485.309 & 739.632 & 1.111 .973 \\
\hline Minha Casa, Minha Vida & Implícito & 432.664 & 555.317 & 536.604 & 634.000 & 518.188 & 381.775 & 267.619 & 280.527 \\
\hline Fundos da Criança e do Adolescente & Implícito & 288.142 & 256.418 & 269.961 & 294.593 & 284.940 & 300.663 & 333.519 & 347.242 \\
\hline Livros Técnicos e Científicos & Implícito & 353.063 & 350.311 & 288.441 & 302.180 & 668.579 & 909.993 & 1.059 .446 & 1.110 .547 \\
\hline $\begin{array}{l}\text { Aquisição de Automóveis - Taxistas e Portadores de } \\
\text { Deficiência (IPI e IOF) }\end{array}$ & Implícito & 268.940 & 232.932 & 329.818 & 483.757 & 559.344 & 609.719 & 751.138 & 1.153 .786 \\
\hline Máquinas e Equipamentos - Cnpq & Implícito & 434.807 & 362.930 & 432.165 & 476.399 & 462.058 & 281.885 & 401.822 & 452.771 \\
\hline Rede Arrecadadora & Implícito & - & - & 99.830 & 244.300 & 287.408 & 270.108 & 269.245 & 269.682 \\
\hline PADIS & Implícito & 14.667 & 32.057 & 125.205 & 226.290 & 237.957 & 259.813 & 272.128 & 286.604 \\
\hline $\begin{array}{l}\text { Doações a Instituições de Ensino e Pesquisa e Entidades Civis } \\
\text { Sem Fins Lucrativos }\end{array}$ & Implícito & 246.721 & 217.493 & 217.829 & 232.762 & 195.772 & 277.922 & 322.738 & 338.305 \\
\hline Cadeira de Rodas e Aparelhos Assistivos & Implícito & 201.221 & 163.191 & 194.825 & 220.308 & 488.470 & 654.934 & 684.713 & 717.739 \\
\hline Dona de Casa & Implícito & 5.503 & 125.073 & 203.415 & 224.718 & 217.378 & 216.135 & 205.443 & 211.081 \\
\hline Incentivo ao Desporto & Implícito & 198.729 & 173.240 & 186.906 & 200.006 & 200.702 & 229.021 & 239.332 & 250.766 \\
\hline Seguro Rural & Implícito & 76.043 & 91.531 & 143.602 & 181.511 & 194.317 & 218.904 & 242.364 & 262.018 \\
\hline REPORTO & Implícito & 161.596 & 182.465 & 269.182 & 255.282 & 284.917 & 236.854 & 212.296 & 202.422 \\
\hline REPENEC & Implícito & 159.928 & 421.122 & 263.441 & 385.483 & 360.041 & 13.486 & - & - \\
\hline Investimentos em Infra-Estrutura & Implícito & - & - & 12.284 & 36.283 & 83.674 & 142.007 & 169.060 & 283.765 \\
\hline Motocicletas & Implícito & 191.522 & 86.066 & 61.371 & 51.510 & 92.591 & 86.849 & 50.229 & 131.550 \\
\hline RENUCLEAR & Implícito & - & - & - & 87.400 & 94.303 & - & - & - \\
\hline Fundos do Idoso & Implícito & 5.206 & 22.828 & 69.071 & 74.421 & 150.227 & 179.138 & 184.365 & 193.142 \\
\hline PRONON & Implícito & - & 3.423 & 67.971 & 70.039 & 122.283 & 69.699 & 71.310 & 74.642 \\
\hline Água Mineral & Implícito & - & 13.110 & 57.870 & 64.100 & 70.340 & 282.095 & 399.783 & 419.066 \\
\hline RETID & Implícito & - & - & - & 59.179 & 62.235 & 4.636 & 14.833 & 16.342 \\
\hline Biodiesel & Implícito & 44.347 & 28.782 & 52.203 & 55.787 & 58.668 & 61.686 & 64.491 & 67.601 \\
\hline Papel - Jornais e Periódicos & Implícito & 50.247 & 57.500 & 110.960 & 118.577 & 156.876 & 14.215 & - & - \\
\hline $\begin{array}{l}\text { TI e TIC - Tecnologia de Informação e Tecnologia da } \\
\text { Informação e da Comunicação }\end{array}$ & Implícito & 102.634 & 12.523 & 35.528 & 37.967 & 39.927 & 424.838 & 181.184 & 189.923 \\
\hline RECINE & Implícito & - & - & 14.839 & 40.711 & 72.597 & 11.631 & 6.300 & 7.736 \\
\hline
\end{tabular}




\begin{tabular}{||l} 
Isenções a Imóveis Rurais (ITR) \\
Promoção de produtos e serviços brasileiros \\
Transporte Escolar \\
Pronas/PCD \\
Creches e Pré-Escolas \\
Indústria Cinematográfica e Radiodifusão \\
PATVD \\
Resíduos Sólidos \\
Evento Esportivo, Cultural e Científico \\
Aerogeradores \\
RETAERO \\
REIF \\
Vale-Cultura \\
Construção Civil \\
PROUCA-REICOMP \\
Crédito Presumido \\
Lojas Francas \\
Empresas montadoras \\
Seguro de Vida e Congêneres (IOF) \\
Produtos Químicos e Farmacêuticos \\
Programa de Alimentação do Trabalhador - PAT (IRPJ) \\
RECOPA \\
PDTI/PDTA \\
Deduções com Benefícios Previdenciários e Assistenciais e \\
FAPI (IRPJ) \\
Trem de Alta Velocidade \\
RECOM \\
Copa do Mundo \\
Empreendimentos Turísticos (IRPJ) \\
Equipamentos Desportivos \\
\end{tabular}

\begin{tabular}{|c|c|c|c|c|c|c|c|c|}
\hline Implícito & 28.660 & 30.209 & 32.083 & 34.114 & 37.195 & 40.445 & 41.839 & 43.372 \\
\hline Implícito & 13.841 & 17.547 & 23.938 & 23.309 & 40.103 & 31.241 & 31.646 & 35.634 \\
\hline Implícito & 21.259 & 104.039 & 42.318 & 23.382 & 5.571 & 180.749 & 202.055 & 211.800 \\
\hline Implícito & - & 2.477 & 10.148 & 11.243 & 93.402 & 34.150 & 34.835 & 36.451 \\
\hline Implícito & - & - & - & 6.016 & 19.351 & 7.660 & 7.227 & 7.576 \\
\hline Implícito & 18.853 & 18.021 & 23.681 & 16.422 & 15.613 & 6.547 & 5.086 & 5.332 \\
\hline Implícito & - & 882 & 1.018 & 4.767 & 4.761 & 3.908 & 297 & - \\
\hline Implícito & 6 & 5 & - & 1.687 & 922 & 2.467 & 6.136 & 6.722 \\
\hline Implícito & - & 11 & 115 & 277 & 349 & 76 & - & 110 \\
\hline Implícito & - & - & - & - & 118.449 & 42.276 & 44.198 & 46.330 \\
\hline Implícito & - & - & 8.436 & - & - & 1.373 & 2.041 & 2.297 \\
\hline Implícito & - & - & - & - & - & - & - & - \\
\hline Implícito & - & - & 3.003 & - & - & - & - & - \\
\hline Implícito & 535.683 & - & - & - & - & - & - & - \\
\hline Implícito & 13.100 & 17.075 & 77 & 64 & 41 & - & - & - \\
\hline Implícito & - & - & - & - & - & - & - & - \\
\hline Implícito & - & - & - & - & - & - & - & - \\
\hline Implícito & - & - & - & - & - & - & - & - \\
\hline Implícito & - & - & - & - & - & - & - & - \\
\hline Implícito & - & - & - & - & - & - & - & - \\
\hline Implícito & - & - & - & - & - & - & - & - \\
\hline Implícito & - & 55.487 & 162.999 & 7.961 & - & - & - & - \\
\hline Implícito & - & - & - & - & - & - & - & - \\
\hline Implícito & - & - & - & - & - & - & - & - \\
\hline Implícito & - & - & - & - & - & - & - & - \\
\hline Implícito & - & - & - & - & - & - & - & - \\
\hline Implícito & - & 3.354 & 24.600 & 94.467 & 7.882 & - & - & - \\
\hline Implícito & - & - & - & - & - & - & - & - \\
\hline Implícito & - & 15 & 5 & - & - & - & - & - \\
\hline
\end{tabular}




\begin{tabular}{|c|c|c|c|c|c|c|c|c|c|}
\hline Telecomunicações em áreas rurais e regiões remotas & Implícito & - & - & - & - & - & 13.296 & 10.984 & 11.514 \\
\hline $\begin{array}{l}\text { Associações de Poupança e Empréstimos e Planos de Poupança } \\
\text { e Investimentos - PAIT }\end{array}$ & Implícito & - & - & - & - & - & - & - & - \\
\hline Bagagem (II e IPI vinculado à importação) & Implícito & - & - & - & - & - & - & - & - \\
\hline Material Promocional (II e IPI vinculado à importação) & Implícito & - & - & - & - & - & - & - & - \\
\hline Adicional ao Frete para Renovação da Marinha Mercante & Implícito & - & - & - & - & - & - & - & - \\
\hline Demais & Implícito & - & - & - & - & - & - & - & - \\
\hline TOTAL & & 204.340 .463 & 237.635 .471 & 300.340.412 & 317.534 .840 & 398.777 .708 & 379.994.245 & 362.911 .726 & 314.199 .763 \\
\hline
\end{tabular}

